\title{
Article \\ Quinoa (Chenopodium quinoa Willd.): Genetic Diversity According to ISSR and SCoT Markers, Relative Gene Expression, and Morpho-Physiological Variation under Salinity Stress
}

\author{
Diaa Abd El-Moneim 1,*(D), Eman I. S. ELsarag ${ }^{2}$, Salman Aloufi ${ }^{3}$, Asmaa M. El-Azraq ${ }^{2}$, \\ Salha Mesfer ALshamrani ${ }^{4}$, Fatmah Ahmed Ahmed Safhi ${ }^{5}$ iD and Amira A. Ibrahim ${ }^{6, *(D)}$
}

Citation: Abd El-Moneim, D.; ELsarag, E.I.S.; Aloufi, S.; El-Azraq, A.M.; ALshamrani, S.M.; Safhi, F.A.A.; Ibrahim, A.A. Quinoa (Chenopodium quinoa Willd.): Genetic Diversity According to ISSR and SCoT Markers, Relative Gene Expression, and Morpho-Physiological Variation under Salinity Stress. Plants 2021, 10, 2802. https://doi.org/10.3390/ plants10122802

Academic Editors: Pasqualina Woodrow and Loredana Filomena Ciarmiello

Received: 4 November 2021 Accepted: 14 December 2021 Published: 17 December 2021

Publisher's Note: MDPI stays neutral with regard to jurisdictional claims in published maps and institutional affiliations.

Copyright: (c) 2021 by the authors. Licensee MDPI, Basel, Switzerland. This article is an open access article distributed under the terms and conditions of the Creative Commons Attribution (CC BY) license (https:/ / creativecommons.org/licenses/by/ $4.0 /)$.
1 Department of Plant Production (Genetic Branch), Faculty of Environmental and Agricultural Sciences, Arish University, El-Arish 45511, Egypt

2 Department of Plant Production (Agronomy Branch), Faculty of Environmental and Agricultural Sciences, Arish University, El-Arish 45511, Egypt; emanelsarag@aru.edu.eg (E.I.S.E.); asmaamoustafaalazrak@gmail.com (A.M.E.-A.)

3 Department of Biotechnology, Faculty of Science, Taif University, P.O. Box 11099, Taif 21944, Saudi Arabia; s.aloufi@tu.edu.sa

4 Department of Biology, College of Science, University of Jeddah, Jeddah 21959, Saudi Arabia; smalshmrane@uj.edu.sa

5 Department of Biology, College of Science, Princess Nourah bint Abdulrahman University, Riyadh 11671, Saudi Arabia; faalsafhi@pnu.edu.sa

6 Plant Protection and Biomolecular Diagnosis Department, Arid Lands Cultivation Research Institute, City of Scientific Research and Technological Applications, New Borg El-Arab, Alexandria 21934, Egypt

* Correspondence: dabdelmoniem@aru.edu.eg (D.A.E.-M.); amiranasreldeen@yahoo.com (A.A.I.); Tel.: +966-540-742-167 (D.A.E.-M.); +20-106-667-7539 (A.A.I.)

Abstract: Quinoa (Chenopodium quinoa Willd.) is a halophytic crop that can withstand a variety of abiotic stresses, including salt. The present research examined the mechanisms of salt tolerance in five different quinoa genotypes at four different salinity levels (control (60), 80, 120, and $160 \mathrm{mM} \mathrm{NaCl}$ ). ISSR and SCoT analysis revealed high polymorphism percentages of $90.91 \%$ and $85.26 \%$, respectively. Furthermore, ISSR 1 and SCOT 7 attained the greatest number of polymorphic amplicons (27 and 26), respectively. Notably, LINE-6 and M-28 genotypes demonstrated the greatest number of unique positive and negative amplicons (50 and 42) generated from ISSR and SCoT, respectively. Protein pattern analysis detected 11 bands with a polymorphism percentage $27.27 \%$ among the quinoa genotypes, with three unique bands distinguishable for the M-28 genotype. Similarity correlation indicated that the highest similarity was between S-10 and Regeolone-3 (0.657), while the lowest similarity was between M-28 and LINE-6 (0.44). Significant variations existed among the studied salinity treatments, genotypes, and the interactions between them. The highest and lowest values for all the studied morpho-physiological and biochemical traits were recorded at 60 and $160 \mathrm{mM} \mathrm{NaCl}$ concentrations, respectively, except for the $\mathrm{Na}$ and proline contents, which exhibited the opposite relationship. The M-28 genotype demonstrated the highest values for all studied characteristics, while the LINE-6 genotype represented the lowest in both seasons. On the other hand, mRNA transcript levels for CqSOS1 did not exhibit differential expression in roots and leaf tissues, while the expression of $C q N H X 1$ was upregulated more in both tissues for the M-28 genotype than for the LINE-6 genotype, and its maximum induction was seen in the leaves. Overall, the genotypes M-28 and LINE-6 were identified as the most and least salinity-tolerant, respectively.

Keywords: quinoa; salinity; morpho-physiological traits; chemical compositions; gene expression; CqSOS1; CqNHX1; ISSR; SCOT 


\section{Introduction}

Over recent decades, the world has experienced significant changes in climate and the subsequent impact on the growth, physiology, and yields of crops. In addition to climate change, short-sighted agricultural practices increased soil salinity in certain areas [1]. Quinoa (Chenopodium quinoa Willd.) belongs to the family Chenopodiacea and has been cultivated in different regions for over 7000 years due to its ability to adapt to various environmental conditions [2-4]. Recently, quinoa has gained global attention due to its high resistance to diverse abiotic stresses such as salinity, drought, those found in forest ecosystems, and heat [5]. It can be cultivated in different environments and geographical areas; as such, quinoa has become an alternative model crop in many marginal arid and semi-arid regions [3]. Its adaptability to various edaphic environmental stresses has led to its substantial genetic diversity, with more than 16,000 accessions stored in seed banks around the world [1]. There are five quinoa ecotypes according to the degree of adaptation to environmental conditions: Altiplano, Salar, Yunga, Valley, and Lowland [6,7].

Quinoa is a multipurpose plant, recently used in the human diet and as an alternative to animal products as a source of protein; quinoa contains high contents of protein (12-18\%), amino acids, bioactive compounds, essential amino acids, fatty acids, and minerals [8,9]. The seeds and leaves of quinoa are used as food, while its biomass is also used in animal feed. Additionally, its high contents of saponins and colorants make it useful for industrial and pharmaceutical purposes [2,10]. Nevertheless, investigating the salt-tolerance capabilities of different quinoa genotypes and measuring their yield stability-without affecting grain quality-is critical to increasing the food security and agricultural productivity of resource-poor and degraded marginal lands. In this regard, estimation of the genetic diversity of quinoa will be helpful in the assessment of conservation and the development of core selections for breeding systems [11,12].

Genotype collection, assessment, and evaluation are essential steps in breeding programs [13]. The quinoa plant has characteristically large morphological properties that can help farmers in plant selection; however, this approach fails to provide genetic information that may restrict breeding strategies $[14,15]$. Salinity stress studies of quinoa are typically based on $\mathrm{Na}$ and $\mathrm{K}$ mineral contents due to their correlation with osmotic pathways and hydrophilic mechanisms [16-18]. Quinoa has a high mineral content $(\mathrm{Na}, \mathrm{K}, \mathrm{Mg}, \mathrm{Ca}$, and P) that researchers tend to focus on when studying plant breeding and the genetic diversity of this sustainable crop.

Several genes encode different mechanisms implemented by salt-tolerant plants when apoplastic $\mathrm{Na}^{+}$levels are high. Salt overly sensitive 1 (SOS1) can facilitate the loading of $\mathrm{Na}^{+}$into xylem vessels from the roots, while NHX1 exchanges $\mathrm{Na}$ and $\mathrm{H}$ and leads to $\mathrm{Na}$ compartmentation in vacuoles [19]. An accumulation of sodium alters the K homeostasis that uses the $\mathrm{Na} / \mathrm{K}$ ratio as an indicator for salinity tolerance in halophytes $[20,21]$. Physiological factors such as membrane transport systems, sodium uptake minimization, and ion compartmentation in cells and tissues are regulated by main genes such as SOS1 and NHX1 [22,23]. The analysis of gene expression levels and tissue specificity will help understand the mechanisms present in C. quinoa. It is possible that these genes also have a role in the molecular mechanisms that regulate salt responses in quinoa.

ISSRs (inter simple sequence repeats) markers are easy to use and repeat. It only needs a small amount of DNA and does not need to know the DNA sequence. ISSR primers are made from SSR motifs, and they can be used on any plant species with a suitable number and distribution of SSR motifs in its genome [24]. Furthermore, Start Codon Targeted (SCoT) polymorphisms are reproducible markers that are based on the short-conserved region in plant genes surrounding the ATG translation start codon; the use of SCoT markers would be much more efficient, especially in comparison to other arbitrary markers, due to the longer primer distances and high annealing temperatures [25]. The SCoT marker design approach does not require any detailed genomic sequence information, making it easier to apply to plants that do not have a reference genome [26]. Because of their high reproducibility and power for detecting polymorphism in quinoa, several investigations were concluded that 
both markers are helpful in genetic variability evaluation [27-29] using ISSR and [29,30] using SCoT. In the same context, SDS-PAGE protein profile analysis is a rapid method to detect and identify the relationships between different quinoa genotypes [31-33].

The lack of characterization and evaluation studies could limit selection and improvement as well as cultivation expansion. Hence, the present study will be of particular value in ongoing efforts to both accelerate the improvement of quinoa and develop core collections that can be used by traditional breeding programs in Egypt. This investigation aimed to (i) study the genetic diversity between studied quinoa genotypes using ISSR, SCoT, and SDS-PAGE protein analysis, (ii) study the physio-morphological and biochemical characters of quinoa genotypes under salinity stress, and (iii) evaluate the relative gene expression using $\mathrm{CqNHX1}$ and $\mathrm{CqSOS1}$ genes for the tolerant and sensitive genotypes.

\section{Materials and Methods}

\subsection{Germplasm, Experimental Setup, and Growth Conditions}

This research was conducted in a shading house at the Faculty of Environmental Agricultural Sciences, Arish University, North Sinai, Egypt, over two winter seasons (2016/2017 and 2017/2018). The names and sources of the genotypes are presented in Table 1. All the studied genotypes were imported by Desert Research Center, Egypt; then, through personal communication, we were granted to evaluate them under North Sinai conditions. For the whole experiment, 60 pots were used; 20 pots were planted with five genotypes (M-28, Q-37, S-10, Regeolone-3, Line-6; 10 seeds/pot) in 3 replications, then four salinity levels (control (60), 80, 120, and $160 \mathrm{mM} \mathrm{NaCl}$ ) were applied for 60 pots after 20 days from planting. Plastic pots $(15 \mathrm{~cm}$ diameter $\times 16 \mathrm{~cm}$ depth) were filled with a $3.00 \mathrm{~kg}$ mixture of sand and clay (1:1). After four days, seedlings were thinned at a rate of 24 seedlings/genotype (in three replicates; 8 seeds/pot). Phosphoric acid $\left(\mathrm{H}_{2} \mathrm{PO}_{5}, 85 \%\right)$ and NPK (20:20:20) were added at rates of $1 \mathrm{~cm} / \mathrm{L}$ and $1 \mathrm{~g} / \mathrm{L}$, respectively. The salinity level treatments were applied from 20 days after planting until three months later. The soil salinity was $4.46 \mathrm{dsm}^{-1}$ before salinity levels application. The harvesting date was 110 days after the sowing date.

Table 1. Name and origin of the studied genotype's.

\begin{tabular}{cc}
\hline Genotype Name & Source \\
\hline M-28 & Denmark \\
Q-37 & Chile \\
S-10 & Denmark \\
Regeolone-3 & Chile \\
LINE-6 & Denmark \\
\hline
\end{tabular}

\subsection{Measurements of Growth and Developmental Parameters}

\subsubsection{Germination Rate}

Grains were sterilized for $20 \mathrm{~min}$ in $20 \% \mathrm{NaOCl}$, rinsed, and soaked for one $\mathrm{h}$ in distilled water. The experiment was conducted at $25 \pm 2{ }^{\circ} \mathrm{C}$ under dark conditions, and the germination was performed using saline water and filter paper in Petri dishes. Salinity treatments were $60,80,120$, and $160 \mathrm{mM} \mathrm{NaCl}$. Twenty-five seeds/genotype were sown in the Petri dishes with three replicates. The germinating seeds were regularly checked from three days after the sowing date. After 20 days, the germination rate (GR) was estimated according to Barlett [34].

\subsubsection{Morpho-Physiological Traits}

Growth traits: Relative Growth Rate (RGR), Crop Growth Rate (CGR), Net Assimilation Rate (NAR)) were measured by collecting randomly three guarded plants from each pot at 45, 60, and 75 days after the sowing date and were computed according to Radford [35]. Physiological traits: Leaf Area (LA) $\left(\mathrm{cm}^{\left.-\mathrm{dsm}^{2}\right)}\right.$ according to Radford [35] Leaf 
Area Index (LAI) according to Beedle [36], plant height $(\mathrm{cm})$, root length $(\mathrm{cm})$, number of leaves/plants, and number of branches/plants were recorded at 75 days after sowing date.

\subsubsection{Yield and Its Components}

Grain weight (g/plant), Harvest Index (HI; \%), 1000-grain weight (g), number of panicles/plants, total weight of panicles/plant (g), and plant fresh weight $(\mathrm{g})$ were measured by collecting randomly five guarded plants from each pot at 110 days after sowing.

\subsubsection{Measurements of Chemical Compositions}

Protein, proline, and mineral (N, P, K, and $\mathrm{Na}$ ) contents were estimated by collecting samples at 60 days after sowing. Protein content: Seed meals were dried at $70{ }^{\circ} \mathrm{C}$ and kept for $\mathrm{N}$ analysis. Protein percentage was determined according to [37]. The formula used for calculation of crude protein was as follows: Protein $\%=(T \times 0.1 \times 14 \times 100 \times 6.2) /($ Weight of sample $\times 1000$ ) Where T: Transmittance. Proline content: $0.5 \mathrm{~g}$ leaves tissue was ground in $10 \mathrm{~mL} \mathrm{3 \%} \mathrm{Solphosalicylic} \mathrm{acid} \mathrm{using} \mathrm{Bates} \mathrm{method} \mathrm{[38].} \mathrm{The} \mathrm{solution} \mathrm{was} \mathrm{purified,} \mathrm{and}$ $2 \mathrm{~mL}$ was taken off from any solutions, then $2 \mathrm{~mL}$ ninhydrin acid agent and $2 \mathrm{~mL}$ acetic acid were added to the theme. Tubes soaked in Ban Mary for $1 \mathrm{~h}$ in $100^{\circ} \mathrm{C}$ and then kept for $30 \mathrm{~m}$ in an ice bath, then $4 \mathrm{~mL}$ toluene added to tubes and two separate layers formed after shaking tubes and keeping them for $20 \mathrm{~s}$. Finally, colored layer absorption during $520 \mathrm{~nm}$ waves and proline content were measured using a standard curve. Leaves mineral contents $\left(\mathrm{N}, \mathrm{P}, \mathrm{K}\right.$, and $\mathrm{Na}$ ): leaves of 5 plants were dried at $70^{\circ} \mathrm{C}$ for $48 \mathrm{~h}$, and $0.5 \mathrm{~g}$ samples were digested by sulfuric acid and hydrogen peroxide to determine mineral content. According to [39]. After proper dilution of digested material, $\mathrm{N}$ was determined using the modified Kjeldahl method. Phosphorus was determined calorimetrically using a spectrophotometer. Potassium and Sodium were determined by using a flame photometer.

\subsection{Molecular Characterization}

\subsubsection{ISSR and SCoT Marker Analysis}

DNA Extraction and ISSR and SCot Amplification

Young leaves of five quinoa genotypes were used for DNA extraction using the CTAB buffer protocol described by Cota-Sanchez et al. [40], and the concentration was determined using nanodrop. Ten pairs of primers from each ISSR and SCoT marker were used in this study. The names and sequences of the primers used are presented in Table S1. Amplification of DNA was carried out according to Zietkiewicz et al. [41] and Collard and Mackill [25] in $20 \mu \mathrm{L}$ of PCR reaction mixture containing $10 \mu \mathrm{L}$ of master (2X TOPsimple DyeMIX-nTaq), $5 \mu \mathrm{L}$ of $(0.1 \mu \mathrm{M})$ for each primer, and $1 \mu \mathrm{L}$ of genomic DNA $(50 \mathrm{ng} / \mu \mathrm{L})$; the final volume of $20 \mu \mathrm{L}$ was achieved using sterile distilled water. The reaction was performed on a Simple Applied Biosystems thermal cycler using the following thermal profile: pre-denaturing for $5 \mathrm{~min}$ at $95^{\circ} \mathrm{C}$, followed by 40 cycles at $94{ }^{\circ} \mathrm{C}$ for $40 \mathrm{~s}$, annealing for $40 \mathrm{~s}$, and $72{ }^{\circ} \mathrm{C}$ for $1 \mathrm{~min}$, with a final incubation time of $5 \mathrm{~min}$ at $72{ }^{\circ} \mathrm{C}$. The products were separated on a $1.5 \%$ agarose gel. Only clear, unambiguous, and reproducible bands are considered a single locus. Data were scored as (1) for presence and (0) for absence for each of five samples. If a band was absent in all the studied genotypes and appears in just one genotype, we consider it a positive, unique band. While if there is a band present in all genotypes and absent in just one genotype, we consider it a negative unique band. The polymorphism information content (PIC) was calculated according to the formula of [42], as follows: PIC $=1-\Sigma p i^{2}$ where pi is the frequency of the $i$ th allele of the locus in eight genotypes.

\subsubsection{Protein Analysis}

Proteins were extracted from leaves of the studied genotypes using $20 \mathrm{mM}$ Tris$\mathrm{Cl}$ extraction buffer ( $\mathrm{pH}$ 8.0) containing two mM EDTA and one mM PMSF. Protein concentration in each sample was determined according to Bradford [43]. SDS-PAGE (Sodium dodecyl sulphate-polyacrylamide gel electrophoresis) of the extracted Leaves 
protein was carried out on 15\% polyacrylamide gel following the method of Laemmli [44]. The electrophoretic profile of leaves proteins of each genotype was recorded as presence (1) or absence (0) of a band of a particular molecular weight. The protein profile was analyzed using a Bio-Rad Gel Documentation System (BIO-RAD-Gel-DocModel2000).

\subsubsection{Gene Expression Analysis}

Based on morpho-physiological analysis, two quinoa genotypes (M-28 and LINE-6) were chosen according to their contrasting salinity tolerances for the gene expression analysis. Ten germinated seeds were transferred into four $60 \times 25 \mathrm{~mm}$ plastic boxes/genotype, with three replicates. The plastic boxes contained growth medium (Hoagland solution), which was changed daily. Seedlings were grown for seven days under normal conditions. On the eighth day, salt treatment was initiated by gradually adding $\mathrm{NaCl}$ to the Hoagland solution. Two boxes of each genotype (with three replicates) were treated with two treatments (control or $80 \mathrm{mM} \mathrm{NaCl}$ ). After two days, the concentration of $\mathrm{NaCl}$ was increased to reach the final concentration of $160 \mathrm{mM} \mathrm{NaCl}$. Overall, the salinity treatment lasted six days. After two days of exposure to the final concentration, plant leaves and roots were harvested and immediately frozen in liquid nitrogen and kept at $-80{ }^{\circ} \mathrm{C}$ for further analysis. Subsequently, total RNA was extracted from $100 \mathrm{mg}$ of leaves or roots using TRIzol reagent described by the manufacturer (Catalog 12183555, Invitrogen, Carlsbad, CA, USA). The mRNA levels of the studied genes were estimated using real-time PCR with an ABI Prism 7700 Sequence Detection System using SYBR Green PCR Master Mix (Applied Biosystems, Austin, TX, USA). SOS1 (salt overly sensitive 1) and NHX1 $\left(\mathrm{Na}^{+} / \mathrm{H}^{+}\right.$ exchanger 1) primers were developed from C. quinoa using methods previously described by Maughan et al. [45] and Morales et al. [46], respectively. The pairs of primers utilized for real-time PCR are presented in Table S2. The GAPDH gene [47] was used to normalize expression data and as a housekeeping gene for the estimation of the relative transcript levels of genes of interest in each comparative analysis.

\subsection{Statistical Analysis}

All data are represented as the mean \pm SD of three replicates. Two-way analysis of variance (ANOVA) was used to test the hypothesis that the genotype and salinity concentration affect the studied characteristics of plants. If there were significant differences between the means, comparisons among different groups were performed using Duncan's multiple range tests [48]. $p$ values $\leq 0.01$ were considered to be statistically significant for all statistical tests. Data and statistical analysis were carried out using Excel 2016 and Minitab V.19. Principal component analysis (PCA) was conducted to study the morphological relationships among the studied quinoa genotypes using PAST software [49]. A cluster dendrogram and matrix plot of the studied genotypes was created based on all the study data (morpho-physiological traits and unique bands generated from molecular markers). Additionally, Pearson correlation among the studied genotypes and all revealed data was computed using PAST software [49]. The heatmap was used to study the similarity and dissimilarity among studied taxa based on morphological traits using the TBtools package [50]. Cluster phylogeny of genotypes based on molecular markers was conducted using dendrogram construction using the unweighted pair group method of averages (UPGMA) in NTSYSpc software version 2.1 [51] and was used for dendrogram construction using the unweighted pair group method of averages (UPGMA).

\section{Results}

\subsection{Genetic Diversity Analysis}

\subsubsection{ISSR and SCoT Marker Characterization}

Ten primers were utilized to study the genetic diversity among the studied quinoa genotypes using ISSR molecular markers, generating 176 total amplicons with molecular sizes ranging from 80 to $1430 \mathrm{bp}$; the ISSR pattern is illustrated in Figure S1. Total polymorphic amplicons from this marker were 160; the greatest number of polymorphic amplicons 
(27) was produced from ISSR 1, and the least polymorphic amplicons (10) were produced from ISSR 3 and ISSR 10. The highest polymorphism percentage (100\%) was generated from ISSR 6 and ISSR 10. The highest PIC was observed in ISSR 8 with a value of 0.88 , and the lowest value was 0.6 seen in ISSR 7 (Table 2).

Table 2. Features of ISSR and SCoT molecular markers used to study the genetic diversity of quinoa genotypes.

\begin{tabular}{|c|c|c|c|c|c|c|c|c|}
\hline \multicolumn{2}{|c|}{$\begin{array}{c}\text { Molecular } \\
\text { Markers }\end{array}$} & \multirow{2}{*}{$\begin{array}{c}\text { Amplicon } \\
\text { Size (bp) } \\
\text { Range (bp) }\end{array}$} & \multirow{2}{*}{$\begin{array}{c}\text { Total No. of } \\
\text { Amplicons } \\
29\end{array}$} & \multirow{2}{*}{$\begin{array}{c}\text { Monomorphic } \\
\text { Amplicons }\end{array}$} & \multirow{2}{*}{$\begin{array}{c}\text { Polymorphic } \\
\text { Amplicons } \\
27\end{array}$} & \multirow{2}{*}{$\begin{array}{c}\begin{array}{c}\text { Unique } \\
\text { Amplicons }\end{array} \\
17\end{array}$} & \multirow{2}{*}{$\begin{array}{c}\% \\
\text { Polymorphism } \\
93.1\end{array}$} & \multirow{2}{*}{$\begin{array}{l}\text { PIC } \\
0.81\end{array}$} \\
\hline \multirow{11}{*}{ ISS } & ISSR 1 & & & & & & & \\
\hline & ISSR 2 & $182-660$ & 18 & 2 & 16 & 6 & 88.89 & 0.76 \\
\hline & ISSR 3 & $215-965$ & 11 & 1 & 10 & 4 & 90.91 & 0.76 \\
\hline & ISSR 4 & $185-845$ & 19 & 2 & 17 & 4 & 89.47 & 0.77 \\
\hline & ISSR 5 & 200-1180 & 19 & 1 & 18 & 8 & 94.74 & 0.81 \\
\hline & ISSR 6 & $145-750$ & 17 & 0 & 17 & 4 & 100 & 0.86 \\
\hline & ISSR 7 & $95-970$ & 20 & 5 & 15 & 8 & 75 & 0.6 \\
\hline & ISSR 8 & $185-925$ & 15 & 0 & 15 & 4 & 100 & 0.88 \\
\hline & ISSR 9 & 80-1430 & 18 & 3 & 15 & 7 & 83.33 & 0.68 \\
\hline & ISSR 10 & 275-1155 & 10 & 0 & 10 & 2 & 100 & 0.77 \\
\hline & Average & - & 32 & 2.91 & 29.09 & 11.64 & $83.30 \%$ & 0.77 \\
\hline \multirow{11}{*}{ SCoT } & SCoT 1 & $215-1030$ & 14 & 2 & 12 & 5 & 85.71 & 0.76 \\
\hline & SCoT 2 & 154-1464 & 20 & 0 & 20 & 5 & 100 & 0.84 \\
\hline & SCoT 3 & $175-840$ & 21 & 0 & 21 & 4 & 100 & 0.83 \\
\hline & SCoT 4 & $300-1240$ & 15 & 1 & 14 & 6 & 93.33 & 0.81 \\
\hline & SCoT 5 & $155-588$ & 10 & 5 & 5 & 2 & 50 & 0.33 \\
\hline & SCoT 6 & $150-790$ & 8 & 3 & 3 & 2 & 37.5 & 0.35 \\
\hline & SCoT 7 & 195-1400 & 26 & 0 & 26 & 5 & 100 & 0.82 \\
\hline & SCoT 8 & 132-1900 & 25 & 0 & 25 & 8 & 100 & 0.82 \\
\hline & SCoT 9 & 190-305 & 9 & 5 & 4 & 0 & 44.44 & 0.35 \\
\hline & SCoT 10 & $225-735$ & 8 & 5 & 3 & 2 & 37.5 & 0.32 \\
\hline & Average & - & 15.6 & 2.1 & 13.3 & 3.8 & $74.85 \%$ & 0.62 \\
\hline
\end{tabular}

PIC: polymorphism information content.

For the SCoT marker, ten primers were used to generate 156 total amplicons with 133 polymorphic amplicons and sizes ranging from 132 to $1900 \mathrm{bp}$; the SCoT pattern is shown in Figure S2. The greatest number of polymorphic amplicons (26) was generated from SCoT 7, and the least polymorphic amplicons (three) were from ScoT 3 and SCoT 10. The highest polymorphism (100\%) was produced from SCoT 2, 3, 7 and 8 , and PIC values generated from all primers varied significantly from 0.84 in SCoT 2 to 0.32 in SCoT 10 (Table 2). The greatest number of positive and negative unique amplicons generated from ISSR characteristics for LINE-6 were 28 and three fragments, respectively, whereas the greatest number of positive, unique amplicons from SCoT characteristics for M-28 was 16 fragments. ISSR marker produced the highest polymorphism percentage with a value of 90.91\% (Table 3). Based on the molecular markers ISSR and SCoT, a cluster dendrogram using UPGMA correlation coefficient was created and is presented in Figure S3. The studied genotypes were classified into two clusters: the first involved LINE-6 genotype with a similarity of $87 \%$, whereas the second involved the other genotypes. The second cluster was classified into two sub-clusters: one included M-28 genotype with a similarity of 78\%, while the second included Q-37, S-10, and Regeolone-3 genotypes. Similarity correlation among the studied genotypes based on molecular markers is demonstrated in Table S3, which indicates that the highest similarity was seen between S-10, and Regeolone3 genotypes with a value of 0.657 , whereas the lowest similarity was seen between M-28 and LINE-6 genotypes with a value of 0.44 . 
Table 3. Comparison between features generated from molecular markers and protein SDS-PAGE for the studied Quinoa genotypes.

\begin{tabular}{|c|c|c|c|c|}
\hline \multirow{2}{*}{\multicolumn{2}{|c|}{ Features }} & \multicolumn{2}{|c|}{ Molecular Markers } & \multirow{2}{*}{$\begin{array}{c}\text { SDS-PAGE } \\
\text { Protein }\end{array}$} \\
\hline & & ISSR & SCoT & \\
\hline \multicolumn{2}{|c|}{ Band size range } & $80-1430 \mathrm{bp}$ & $132-1900 \mathrm{bp}$ & 12-200 KDa \\
\hline \multicolumn{2}{|c|}{ Total bands } & 176 & 156 & 11 \\
\hline \multicolumn{2}{|c|}{ Polymorphic bands } & 160 & 133 & 3 \\
\hline \multirow[t]{2}{*}{ Unique bands } & Positive & $\begin{array}{c}19 \text { (M-28), 5(Q-37), } 8 \text { (S-10), } 4 \\
\text { (Regeolone-3), 28(LINE-6) }\end{array}$ & $\begin{array}{l}19 \text { (M-28), 1(Q-37), } 2 \\
(\mathrm{~S}-10), 16 \text { (LINE-6) }\end{array}$ & $3(\mathrm{M}-28)$ \\
\hline & Negative & 1(M-28), 3(LINE-6) & 3 (M-28), 3 (LINE-6) & - \\
\hline \multicolumn{2}{|c|}{$\%$ Polymorphism } & $90.91 \%$ & $85.26 \%$ & $27.27 \%$ \\
\hline
\end{tabular}

\subsubsection{Protein Pattern (SDS-PAGE)}

Eleven total protein bands were recorded in quinoa genotypes with molecular weights varying from 12 to $200 \mathrm{KDa}$, with three polymorphic bands detected as unique characteristic bands which distinguished the M-28 genotype. The polymorphism percentage among the studied quinoa was $27.27 \%$ (Table 3). The protein profile is illustrated in Figure 1.

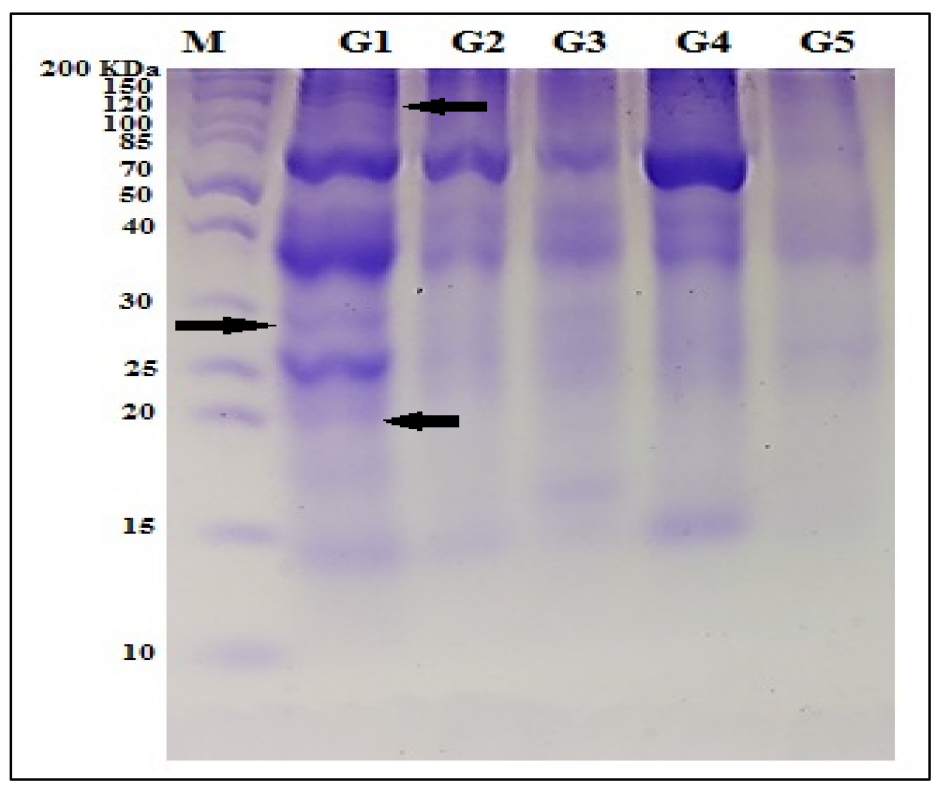

Figure 1. Protein SDS-PAGE profile for the studied Quinoa genotypes, G1: M-28; G2: Q-37; G3: S-10; G4: Regeolone-3; G5: LINE-6; arrows: unique bands for M-28 genotype.

\subsection{Overall Performance of Morpho-Physiological Traits under Salinity Stress}

Five quinoa genotypes were grown under four different conditions: $60,80,120$, or $160 \mathrm{mM} \mathrm{NaCl}$ was added. Analysis of variance revealed significant variations between the studied salinity concentrations for different genotypes. In this regard, the highest and lowest values for all studied characteristics in both seasons were obtained for the 60 and $160 \mathrm{mM} \mathrm{NaCl}$ treatments, respectively; however, sodium $(\mathrm{Na})$ and proline contents revealed the opposite relationship to $\mathrm{NaCl}$ treatment (data not shown). In the same trend, ANOVA revealed significant differences between the studied genotypes at the various salinity treatments. M-28 genotype was found to have the highest values for all the studied traits, while LINE-6 genotype represented the lowest in both seasons (data not shown).

On the other hand, ANOVA for germination analysis, growth analysis, yield, components, and chemical composition parameters revealed that the interactions between treatments and genotypes were significant at $p \leq 0.01$. The data presented in Figure 2 indicate that the highest values for germination analysis (77.27 and 92.18) were obtained by $\mathrm{M}-28$ genotype under $60 \mathrm{mM} \mathrm{NaCl}$ in the 1st and 2nd growing seasons, respectively. 
Meanwhile, the lowest values (40.35 and 55.27) were exhibited by LINE-6 genotypes under $160 \mathrm{mM} \mathrm{NaCl}$ in the 1st and 2nd growing seasons, respectively. Likewise, the M-28 genotype recorded the highest values for growth traits, including plant height (13.31 and $15.16 \mathrm{~cm})$, root length $(8.41$ and $9.58 \mathrm{~cm})$, number of leaves/plant $(16.44$ and $20.44 \mathrm{~cm})$, number of branches/plant (8.22 and 12.22), and leaf area $(5.77$ and $6.56 \mathrm{~cm})$, for the 1st and 2nd growing seasons, respectively, under $60 \mathrm{mM} \mathrm{NaCl}$ treatment. Furthermore, the LINE-6 genotype presented the lowest values for the same traits $(6.30$ and $8.04 \mathrm{~cm}, 2.79$ and $3.79 \mathrm{~cm}$, 9.22 and $13.22,3.33$ and 7.33 , and 0.86 and $1.76 \mathrm{~cm}$ ) for the 1st and 2nd growing seasons, respectively, under $160 \mathrm{mM} \mathrm{NaCl}$ treatment. Figure 2 demonstrates that the highest growth analysis trait (RGR, CGR, NAR, and LAI) values (14.18 and $14.58 \mathrm{~g} / \mathrm{g} /$ day; 356.67 and $366.57 \mathrm{~g} / \mathrm{g} /$ day.cm $\mathrm{cm}^{2} ; 442.1$ and $1025 \mathrm{gm}^{-2}$ day $^{-1}$; and 0.11 and 0.13 ) for the 1 st and 2 nd growing seasons, respectively were consistently obtained by M- 28 genotype under $60 \mathrm{mM}$ $\mathrm{NaCl}$ treatment. Additionally, LINE-6 genotype attained the lowest values for RGR $(0.31$ and $0.30 \mathrm{~g} / \mathrm{g} /$ day $)$, CGR $\left(7.86\right.$ and $7.61 \mathrm{~g} / \mathrm{g} /$ day $\left.\cdot \mathrm{cm}^{2}\right)$, NAR $\left(0.42\right.$ and $48 \mathrm{gm}^{-2}$ day $\left.^{-1}\right)$, and LAI ( 0.01 and 0.03$)$ under $160 \mathrm{mM} \mathrm{NaCl}$ treatment in both seasons.

The results presented in Figure 3 indicate that the maximum values for grain weight (10.35 and $13.29 \mathrm{~g})$, harvest index (37.0\% and $47.0 \%), 1000$-grain weight (2.80 and $3.84 \mathrm{~g})$, number of panicles per plant (6.00 and 12.66), and weight of panicles/plant (3.00 and $5.09 \mathrm{~g}$ ) were obtained by M-28 genotype under $60 \mathrm{mM} \mathrm{NaCl}$ treatment in both seasons. On the other hand, the minimum values (1.7 and $2.63 \mathrm{~g} ; 13.0 \%$ and $27.0 \%$; 0.91 and $1.03 \mathrm{~g} ; 1.00$ and 2.00; and 0.84 and $1.07 \mathrm{~g}$ ) of the studied traits were detected in LINE-6 genotype under $160 \mathrm{mM} \mathrm{NaCl}$. In the same context, the M-28 genotype recorded the highest value for plant fresh weight $(30.37 \mathrm{~g})$, while the LINE-6 genotype with $160 \mathrm{mM} \mathrm{NaCl}$ treatment attained the lowest value $(9.22 \mathrm{~g})$.

Principle component analysis (PCA) indicating morphological trait variation among the studied genotypes is presented in Figure 4. The first and second components of PCA revealed a total variation of $91.228 \%$ and $6.877 \%$, respectively, with a total value of $98.105 \%$. The axes indicated that the most significant traits which can vary among genotypes were harvest index $(\mathrm{HI})$, grain weight $(\mathrm{GW})$, and plant height $(\mathrm{PH})$.

Due to the importance of ISSR and SCoT data in distinguishing the studied genotypes, the relationships between the studied morpho-physiological traits and the unique bands generated from molecular markers were further analyzed. A cluster dendrogram was generated using the UPGMA correlation coefficient, which classified the studied genotypes into two clusters: one contained LINE-6 genotype separated from the other genotypes, and the second cluster was further divided into two sub-clusters, with one containing genotypes M-28 and S-10 and the second containing genotypes Q-37 and Regeolone-3 genotypes. This result confirmed the previous finding that genotype LINE-6 is the least salt tolerant of the studied genotypes (Figure S4). To predict and identify the specific potential unique bands that might be responsible for salinity tolerance in the studied genotypes, a Pearson correlation done among some of the essential studied traits under salinity stress and all the unique bands generated from the studied genotypes (Figure 5). The results clearly stated that the unique bands generated from ISSR3 and SCoT6 primers had a high correlation with all the studied traits under salinity stress. From those unique bands, two bands were generated from the M28 genotype, and two bands were generated from the LINE6 genotype. Oppositely, there was a negative correlation between SCoT 10 and all the selected morphological traits. These bands might be considered helpful markers linked to salinity tolerance or sensitivity in quinoa breeding programmers however, further studies aimed at purification, sequencing and analysis of these bands might be necessary in future work. 


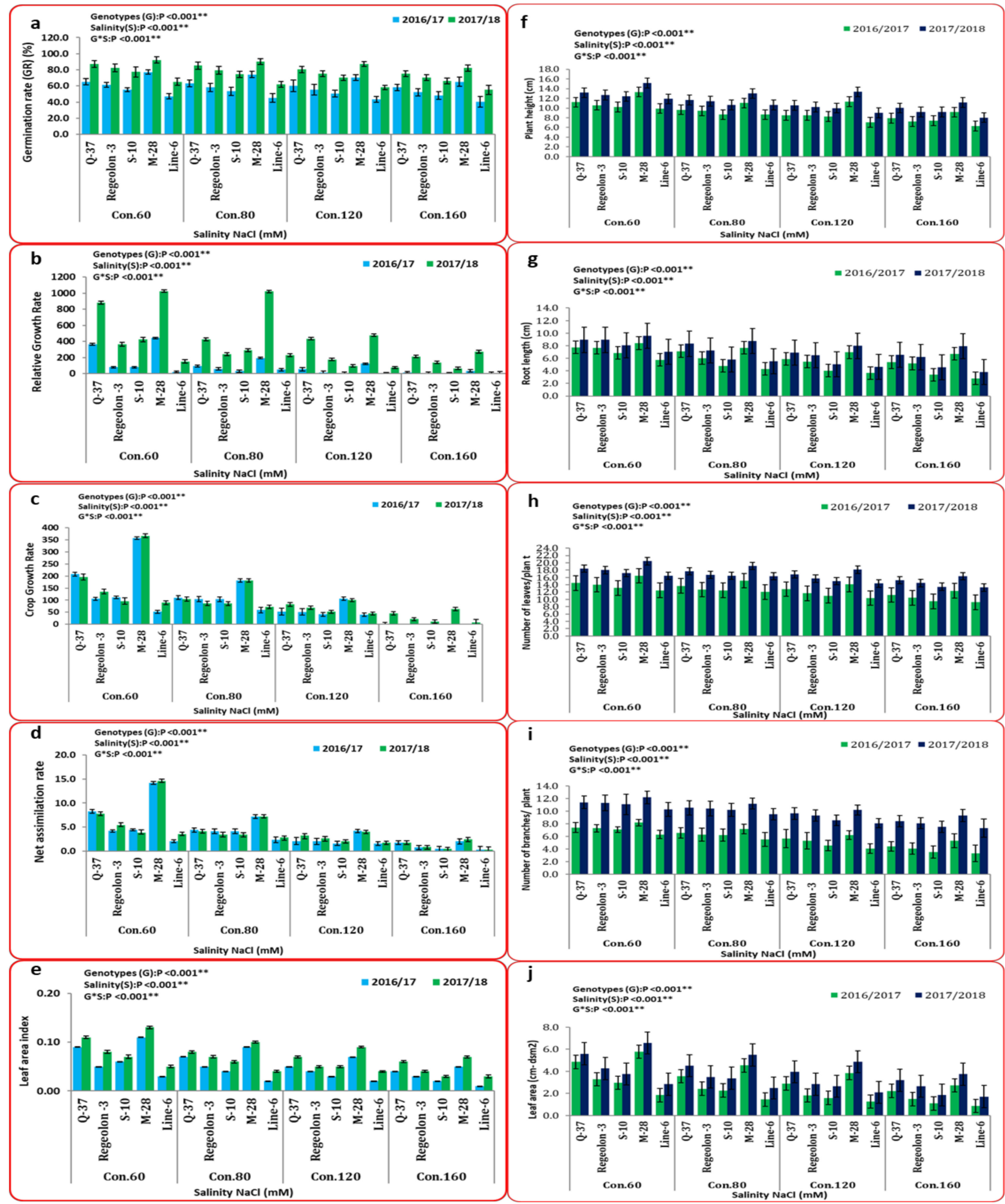

Figure 2. Mean performance (combined data of two seasons) represented as (mean \pm SD) for (a) germination rate, Growth traits: (b) relative growth rate, (c) crop growth rate, (d) net assimilation rate, physiological traits: (e) leaf area index, (f) plant height $(\mathrm{cm}),(\mathrm{g})$ root length $(\mathrm{cm}),(\mathbf{h})$ number of leaves/plants, (i) number of branches/plants, and (j) leaf area. All data are means of three replicates. Two-way ANOVA was performed to determine the effect of different quinoa genotypes on the studied traits. For all statistical tests, $p$ values $\leq 0.01{ }^{* *}$ were considered highly statistically significant.at $0.01 \%$ probability level. 


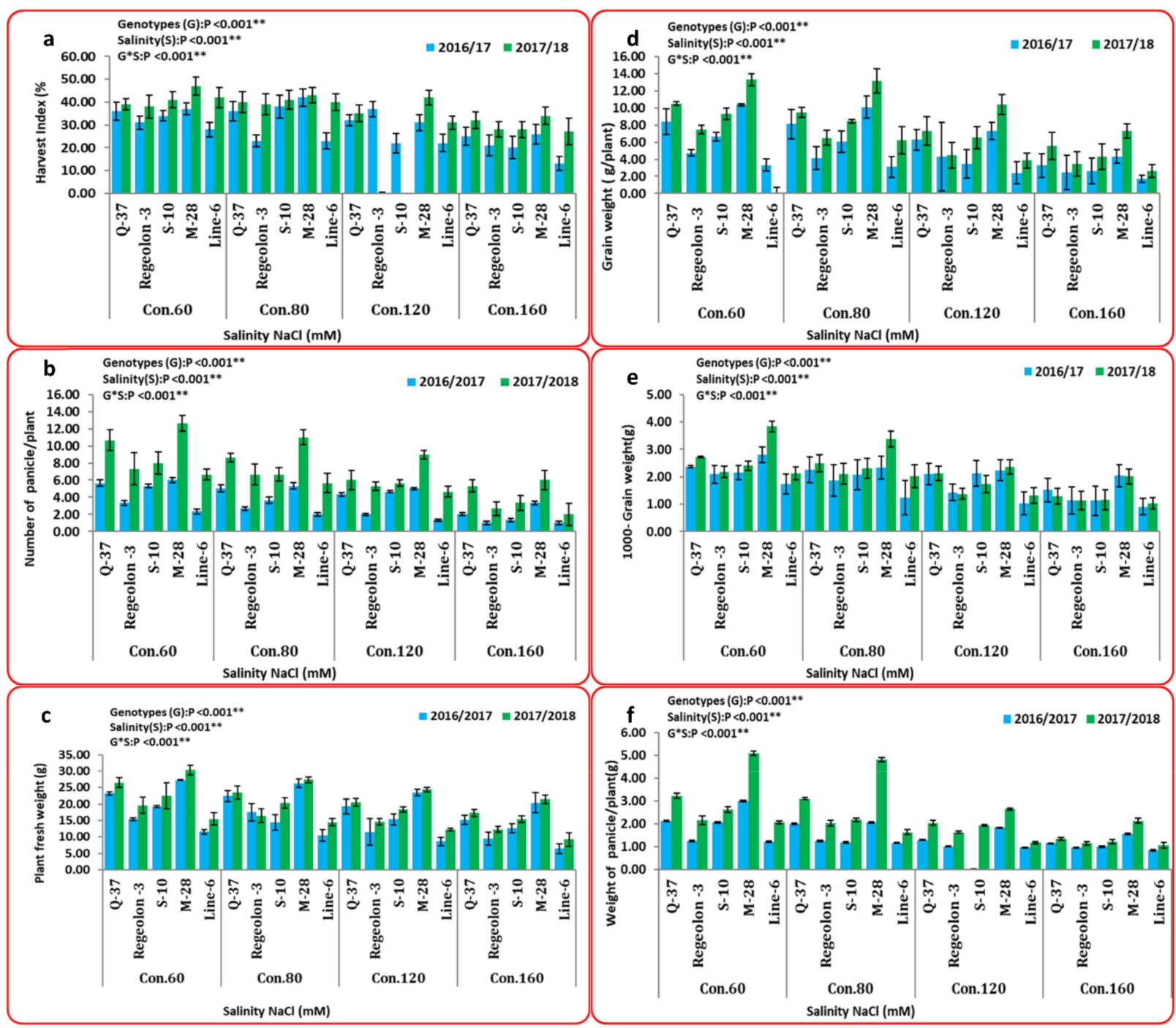

Figure 3. Mean performance (combined data of two seasons) represented as (mean $\pm \mathrm{SD}$ ) for yield and its component traits: (a) harvest index (HI; \%), (b) number of panicles/plants, (c) plant fresh weight (g), (d) grain weight (g/plant), (e)1000-grain weight $(\mathrm{g})$ and (f) weight of panicles/plant $(\mathrm{g})$. All data are means of three replicates. Two-way ANOVA was performed to test the effect of different quinoa genotypes on the studied traits. For all statistical tests, $p$ values $\leq 0.01{ }^{* *}$ were considered highly statistically significant.at $0.01 \%$ probability level. 


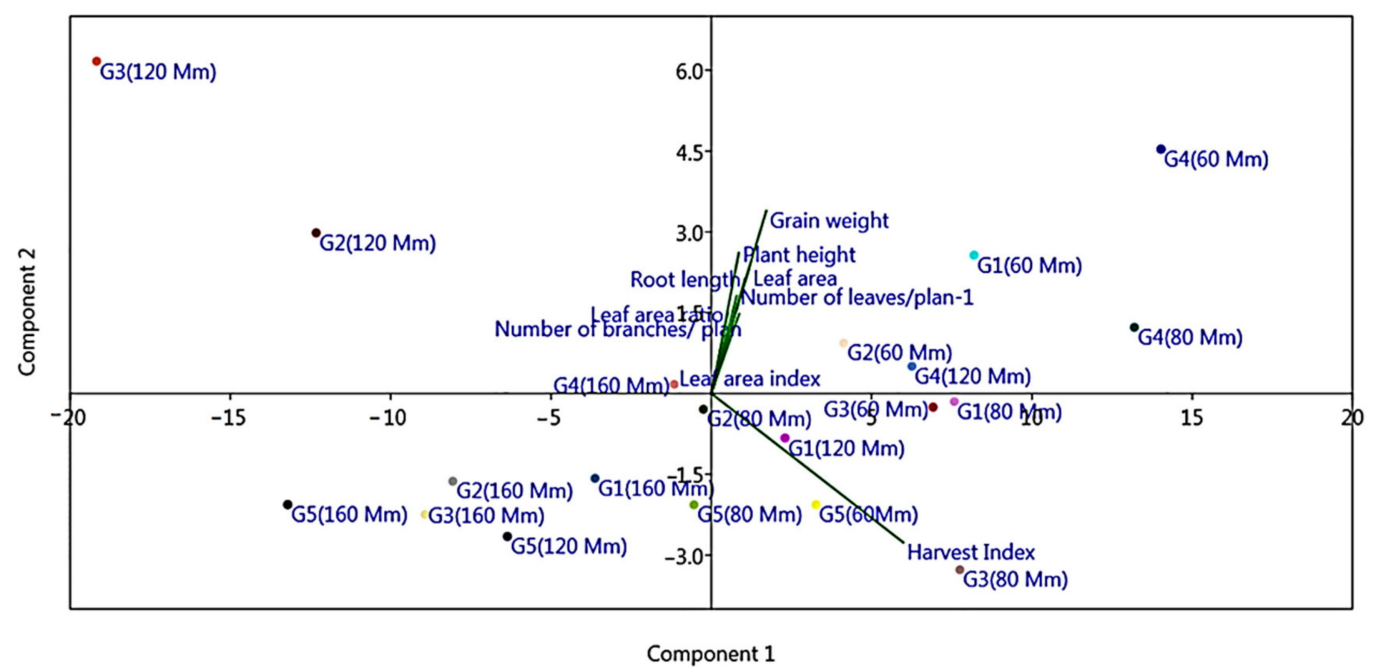

Figure 4. Principal component analysis (PCA) of the quantitative morphological traits for the studied treated quinoa genotypes. The first component demonstrated variance of $91.228 \%$ and the second component demonstrated variance of 6.877\%; G1: M-28; G2: Q-37; G3: S-10; G4: Regeolone-3; G5: LINE-6.

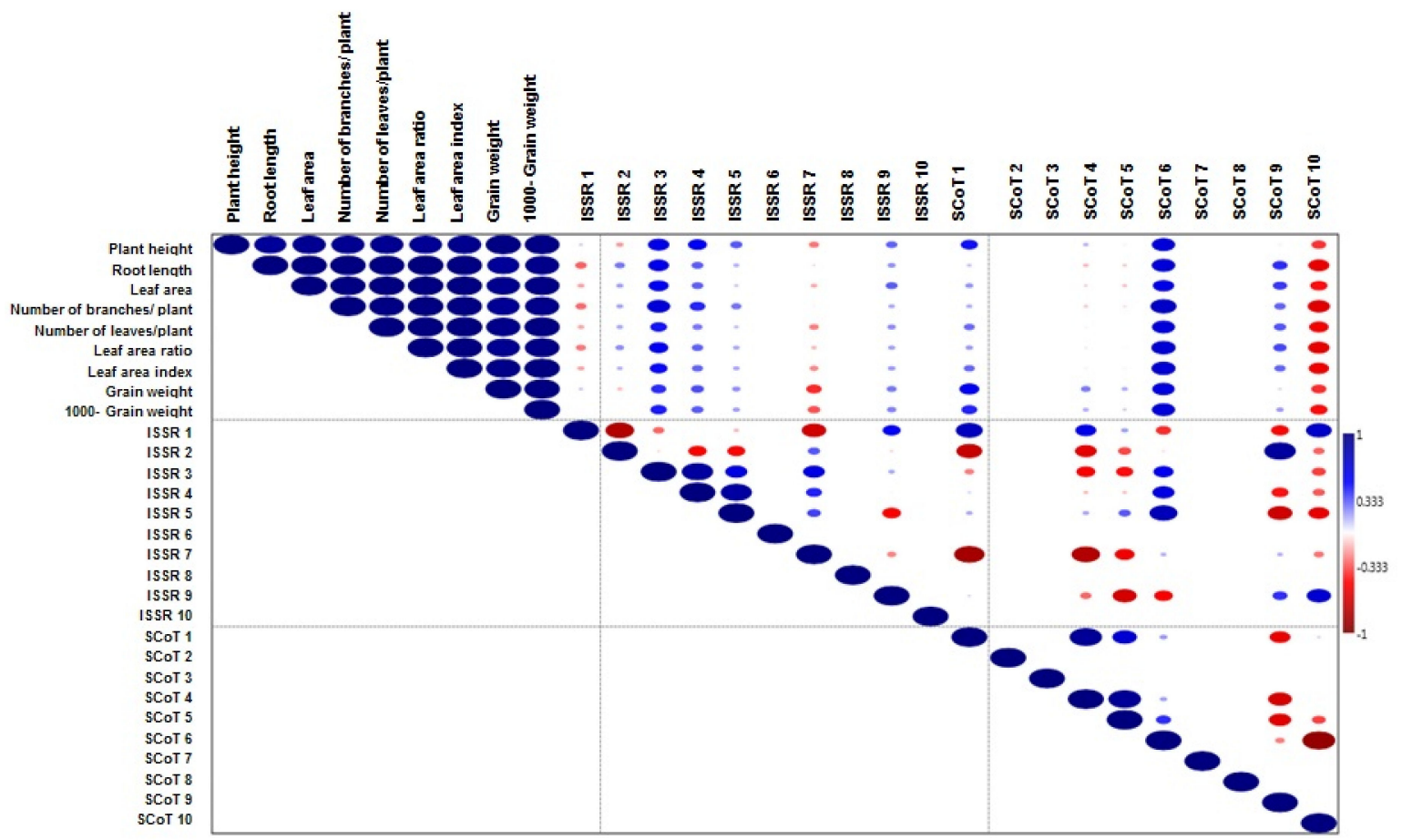

Figure 5. Pearson Correlation among some (morpho-physiological traits \& molecular attributes). The blue color indicates a positive correlation, and the red color indicates a negative correlation. The size of the circle, proportional to the correlation coefficient and intensity of color, represented the magnitude of the value.

\subsection{Biochemical Analysis under Salinity Stress}

The chemical composition results presented in Figure 6 indicate significant differences between salinity and genotypes. The highest recorded means for $\mathrm{K}(7.80 \%$ and $8.45 \%)$, $\mathrm{P}$ $(4.46 \%$ and $6.18 \%), \mathrm{N}(6.01 \%$ and $9.47 \%)$, and protein $(12.25 \%$ and $13.28 \%)$ contents in the 1st and 2nd growing season, respectively, were achieved by M-28 genotype under $60 \mathrm{mM}$ $\mathrm{NaCl}$. On the other hand, LINE-6 genotype under $160 \mathrm{mM} \mathrm{NaCl}$ treatment demonstrated the lowest means $(0.33 \%$ and $1.05 \% ; 0.22 \%$ and $0.97 \% ; 1.77 \%$ and $1.51 \% ; 2.10 \%$ and $2.88 \%)$ for $\mathrm{K}, \mathrm{P}, \mathrm{N}$, and protein content, respectively in both seasons. Additionally, the maximum values for $\mathrm{Na}(8.80 \%$ and $9.44 \%)$ and proline $(0.65 \%$ and $0.73 \%)$ were achieved by the M-28 
genotype with $160 \mathrm{mM} \mathrm{NaCl}$ treatment in both seasons. However, the minimum values for $\mathrm{Na}(1.12 \%$ and $9.44 \%)$ and proline $(0.02 \%$ and $0.03 \%)$ were found in LINE-6 genotype with $60 \mathrm{mM} \mathrm{NaCl}$ treatment in both seasons.

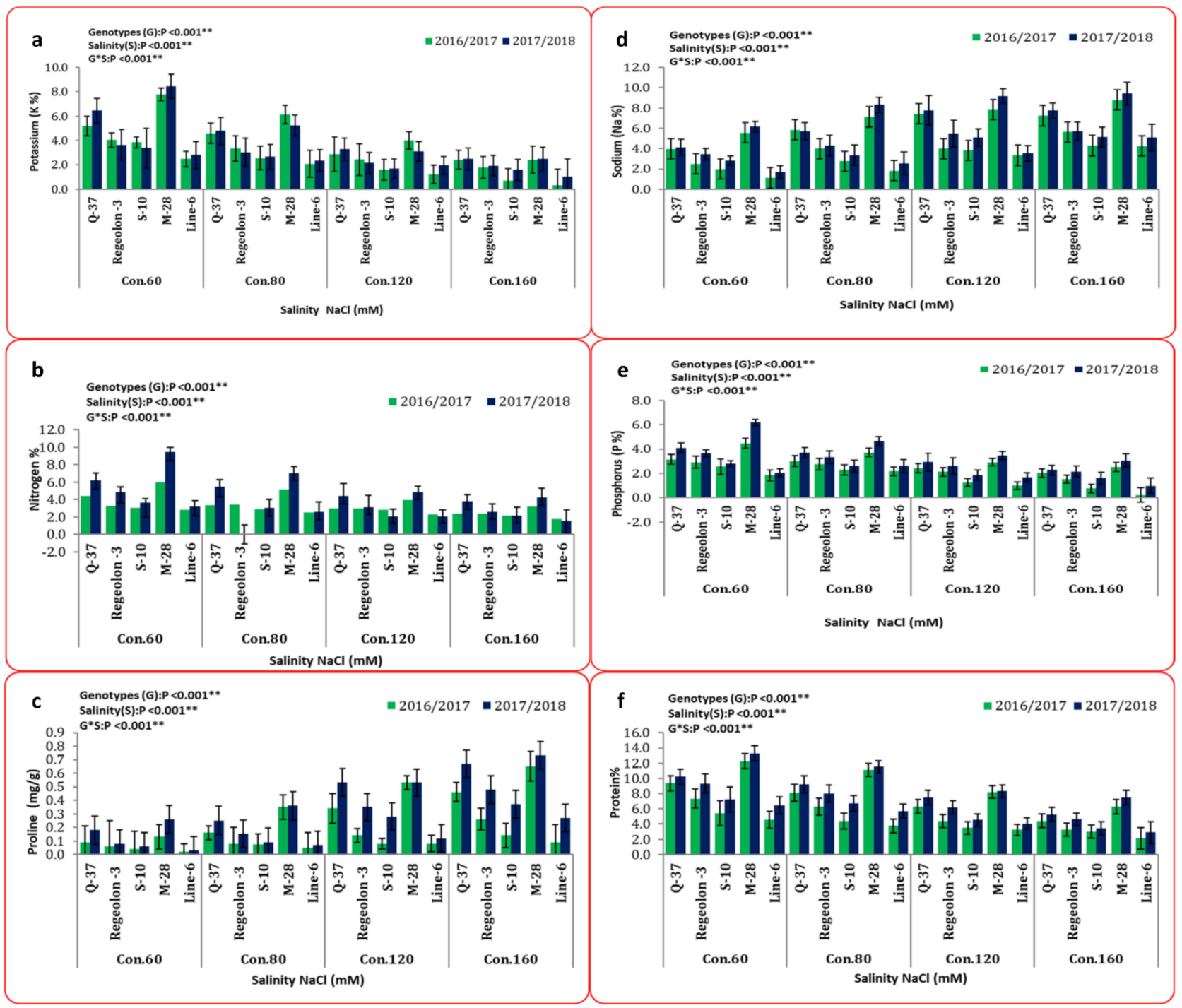

Figure 6. Mean performance (combined data of two seasons) represented as (mean $\pm \mathrm{SD}$ ) for biochemicals traits: (a) potassium, (b) Nitrogen, (c) proline, (d) sodium, (e) phosphorus, and (f) protein. All data are means of three replicates. Two-way ANOVA was performed to test the effect of different quinoa genotypes on the studied traits. For all statistical tests, $p$ values $\leq 0.01 * *$ were considered highly statistically significant.at $0.01 \%$ probability level.

The heat map presented in Figure 7 shows the variations in elements and phytochemicals between the studied quinoa genotypes under salinity stress. The treated genotypes were separated into two groups: the first included M-28 and Regeolone-3 genotypes treated with different concentrations of $\mathrm{NaCl}$, while the second included the other three genotypes (Q-37, S-10, and LINE-6) also treated with different concentrations of $\mathrm{NaCl}$. The red color indicates high similarity between the studied treatments, while blue indicates low similarity. 


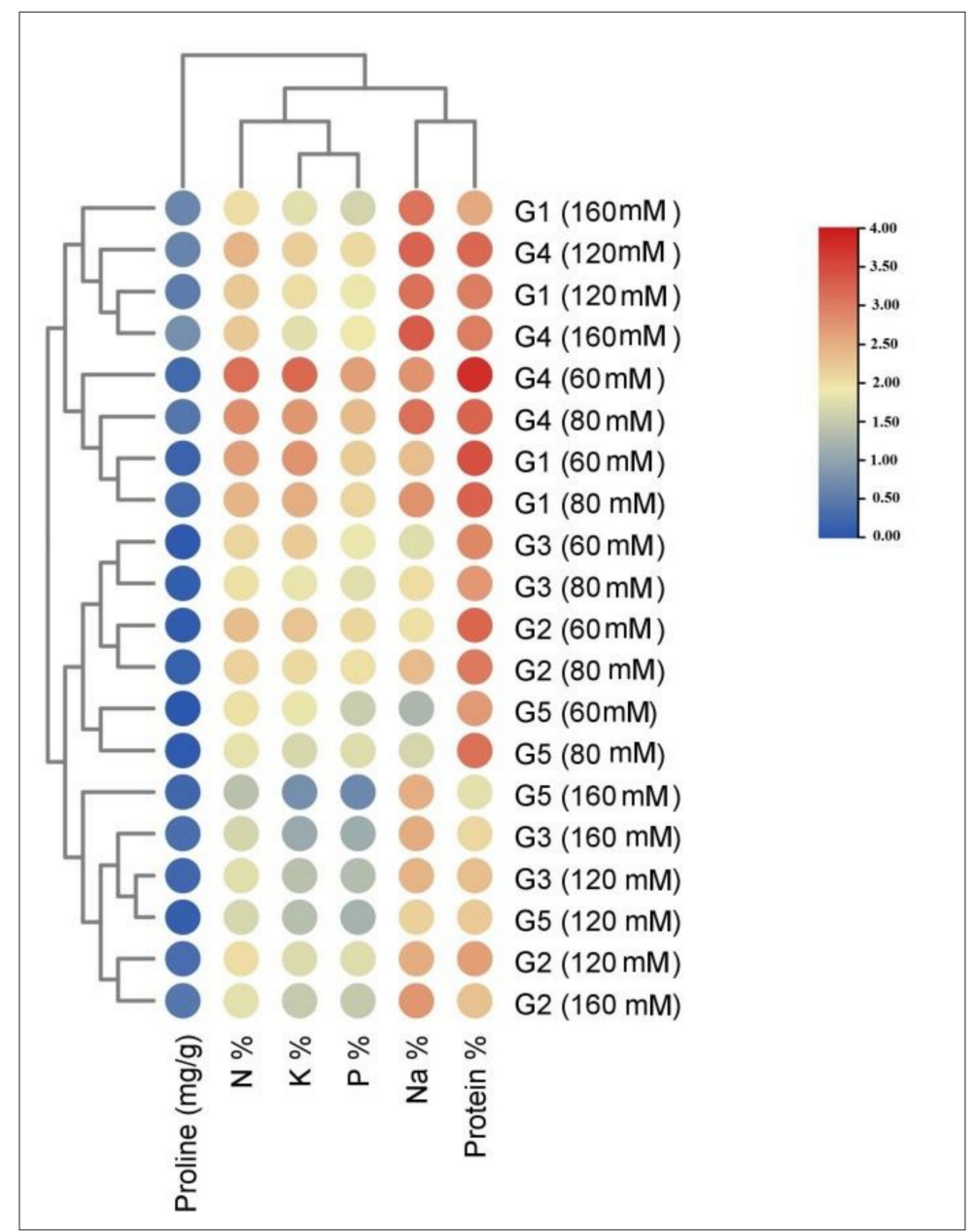

Figure 7. Heat map based on elements and phytochemical compounds of quinoa genotypes treated with different concentrations of NaCl; G1: M-28; G2: Q-37; G3: S-10; G4: Regeolone-3; G5: Line -6.

\subsection{Gene Expression Analysis under Salinity Stress}

Analysis of CqSOS1 and CqNHX1 gene expression was conducted for M-28 genotype (tolerant) and LINE-6 genotype (sensitive) quinoa treated with $160 \mathrm{mM} \mathrm{NaCl}$, using qPCR to quantify the role of each salt-coping mechanism. Figure 8 presents the transcript level of CqSOS1 in treated genotypes compared with untreated ones. Interestingly, our results demonstrate that the expression of CqSOS1 in both studied genotypes and tissues was downregulated compared with that seen in nontreated seedlings.

Moreover, the reduction percentage of the roots of the LINE-6 genotype was lower than that of the M-28 genotype. Meanwhile, the reduction percentage of the leaves demonstrated the opposite trend. In addition, the CqNHX1 transcript level was investigated in treated genotypes and is compared with that of untreated genotypes in Figure 9. mRNA transcript level was higher in leaves than in roots. It was clear that leaf expression sharply increased 10-fold for the tolerant genotype (M-28), while the sensitive genotype (LINE-6) increased just 2-fold, compared with untreated samples. In a similar trend, root samples exhibited upregulation in both genotypes, but the expression in the tolerant genotype was 1.5 times higher than that of the sensitive genotype. 


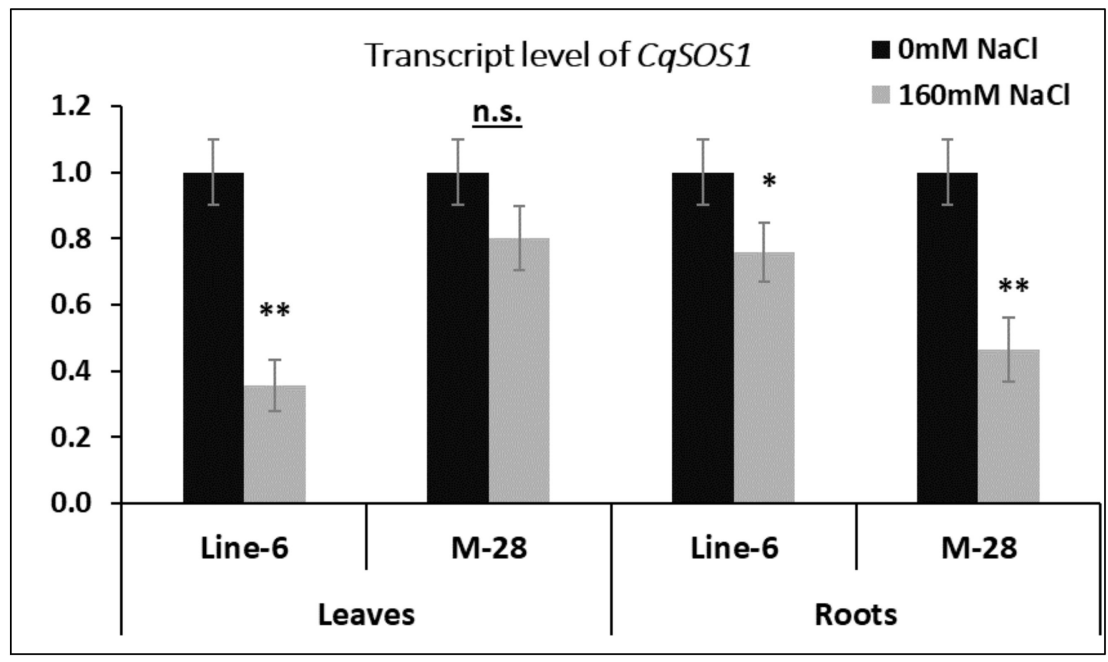

Figure 8. Expression analysis of CqSOS1. Data represent leaves and roots of two quinoa genotypes. Twelve-day-old seedlings were gradually treated with $160 \mathrm{mM} \mathrm{NaCl}$ over six days. Results are presented as the mean fold-change in relative expression over the control from three biological and technical replicates, normalized to GAPDH (reference) gene expression. Bars represent standard deviation. ${ }^{*}, *$ Significant and highly significant at $0.01 \%$ probability level.

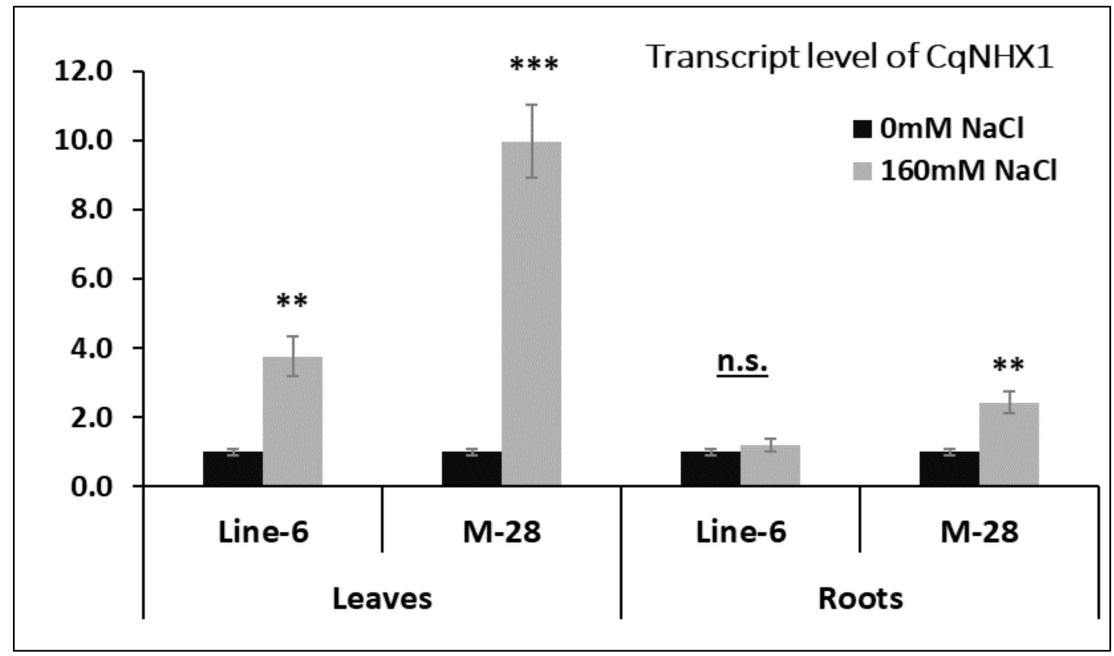

Figure 9. Expression analysis of $C q N H X 1$. Data represent leaves and roots of two quinoa genotypes. Twelve-day-old seedlings were gradually treated with $160 \mathrm{mM} \mathrm{NaCl}$ over six days. Results are presented as the mean fold-change in relative expression over the control from three biological and technical replicates, normalized to GAPDH (reference) gene expression. Bars represent standard deviation. ${ }^{* *}{ }^{* * *}$ Significant and highly significant at $0.01 \%$ probability level.

To clarify correlation between relative gene expressions SOS1 and NHX1 genes and morpho-physiological traits Principal Component Analysis (PCA) was computed for M-28 and Line-6 quinoa genotypes under salinity stress (Figure 10). The first two principal components (PC1 \&PC2) with Eginvalue greater than 2.6 and explained total variance $74.155 \%$ and $20.521 \%$ respectively. The eigenvalues are considered the best measure for the quality of ordination and of the strength of the genotypes-morpho-physiological relationship. Results from PCA indicated that relative gene expression of NHX1 in leaves was the most significant one, followed by grain weight, leaf area and plant height. Length of the arrow refers to the most powerful for NHX1 gene variable and the direction of the arrow points refers to highest morpho-physiological traits change. 


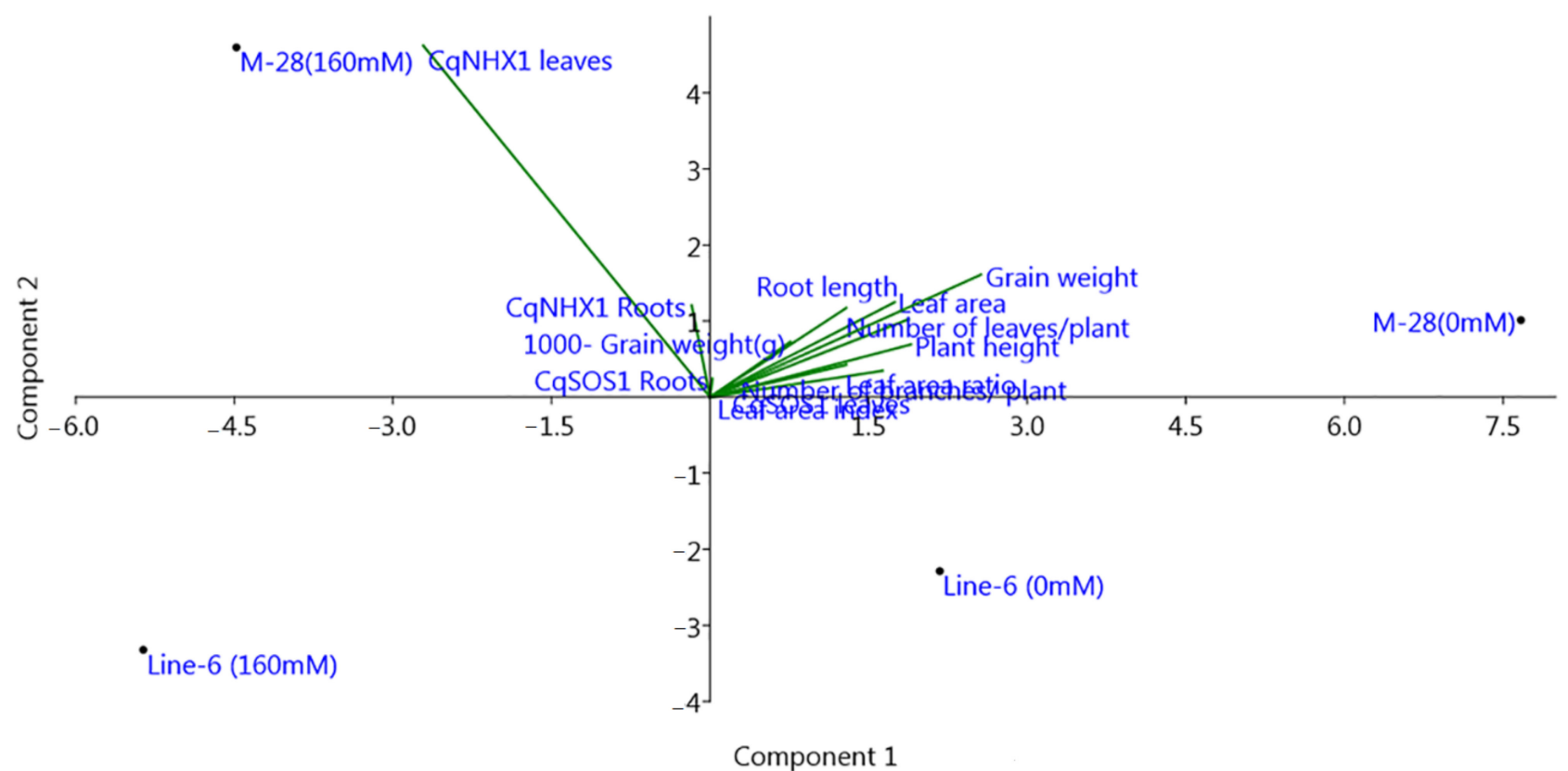

Figure 10. Principal component analysis (PCA) of some morpho-physiological traits and relative gene expressions for M-28 and Line- 6 genotypes under salinity stress. The first component demonstrated variance of $74.155 \%$ and the second component demonstrated variance of $20.521 \%$.

\section{Discussion}

A genetic variability is an important tool for discerning information regarding the adaptation of species and cultivars to biotic and abiotic conditions, which lead to changes in the genetic composition of these plants. Many molecular markers have been used to estimate the genetic diversity of quinoa in several investigations $[13,14,52]$. ISSR markers are a valuable genetic tool for assessing the relationships among quinoa genotypes $[53,54]$. In this investigation, ISSR markers generated 176 total bands with 68 positive unique bands and four negative bands; these unique bands were used for species and genotype identification $[55,56]$. ISSR markers were also used to detect genetic variations in quinoa [57]. The polymorphism percentage revealed by ISSR primers was $90.91 \%$ higher than both polymorphism percentages produced by the same marker in Al-Naggar et al. [58] and SaadAllah and Youssef [59]'s studies, which reported values of $61.83 \%$ and $31.47 \%$, respectively. Polymorphism information content (PIC) in this study varied from the lowest value of 0.32 (revealed by SCoT) to the highest value of 0.88 (displayed by ISSR). The value of PIC ranges from 0 to 1 , with values closer to 1 indicating higher polymorphism. Additionally, PIC is classified as high informative (PIC $>0.5)$, moderate informative $(0.25<\mathrm{PIC}<0.5)$, and low informative (PIC < 0. 25) [60]. The value of PIC in this study was higher than both the values of PIC, ranging from $0.10-0.25$, revealed by the SRAP marker for 135 quinoa accessions in Thailand [61], and the mean PIC value produced using SRAP of 0.59 for 32 quinoa genotypes in Egypt [62]. Concerning polymorphism, the ISSR marker was superior and more efficient than the SCoT marker in this study, with ISSR detecting $90.91 \%$ while SCoT detected $85.26 \%$. Similar results were obtained by Abd El-Moneim [63] and Gowayed and Abd El-Moneim [64] for wheat and by El-Mansy et al. [65] for tomato. On the other hand, Abdein et al. $[66,67]$ revealed that SCoT showed more polymorphism than ISSR in tomato and squash, respectively. A cluster dendrogram based on molecular markers divided the studied genotypes into two clusters. Genotype M-28 in one cluster and LINE-6 in the other cluster, which is in agreement with similarity indices and provides the lowest similarity between M-28 and LINE-6 genotypes.

Quinoa contains main protein fractions from albumins and globulins. The globulins (chenopodin) are called 221 11S-type, which include two subunits: acidic subunits, with a 
molecular weight range of 30-40 KDa, and basic subunits, with a molecular weight range of $20-25 \mathrm{KDa}$. The proteins in the lower protein band, with a molecular weight range of $8-11 \mathrm{KDa}$, are called $2 \mathrm{~S}$-type proteins $[10,22,23,68]$. The present study revealed that the SDS-PAGE technique exhibited protein band alterations among the studied quinoa genotypes. Genotype M-28 had three unique bands with molecular weights of 20, 25, and $29 \mathrm{KDa}$; this differentiation is based on the difference in intensities and molecular weights of polypeptides that are the final product of the transcription and translation process [69]. Quinoa genotypes had a low level of protein polymorphism of $27.27 \%$; this low percentage may be due to the protein-conserving nature of seeds [70,71].

Several authors have documented that quinoa genotypes exhibit significant genetic diversity in agro-physiological reactions when grown under saline conditions [72,73]. In the same trend, in this research, all of the studied traits were significantly affected by different artificial salinity levels. Figures 2, 3 and 6 demonstrated that all of the studied parameters decreased-except for Na and proline levels-with increasing salinity. Furthermore, the variation between the studied genotypes in response to salinity was distinct.

The most sensitive phase for plants, including halophytes, is germination [74]. In most quinoa genotypes, concentrations of 100 to $250 \mathrm{mM} \mathrm{NaCl}$ have no effect on germination rates [75]. Nevertheless, germination is delayed at doses of 150 to $250 \mathrm{mM} \mathrm{NaCl}$ [76]. In this study, reduced germination under salt stress conditions may have been due to the osmotic potential. Similar results were revealed by [77]. Growth parameters and leaf area of the investigated genotypes were impacted by salinity stress, primarily through a decrease in the photosynthesis rate, an imbalance between the photosynthesis and respiration rates of the entire plant or decreased water uptake. This result is in line with Saleem et al. [78] and Long [79]. The altered and/or reduced supply of certain plant nutrients might cause a lower growth rate in certain genotypes, resulting in less relative growth. Similar results were observed by Talebnejad et al. [80] for NAR and Islam et al. [81] for CGR and RGR. On the other hand, Riccardi et al. [82] demonstrated that RGR and NAR were not significantly different between saline- and nonsaline-treated plants.

Plant height is one of the most sensitive traits affected by salt stress, according to Jacobsen et al. [83]. In this investigation, plant height was reduced, potentially due to the toxic impact of the $\mathrm{NaCl}$ utilized, unequal nutrient uptake, or reduced cell division and DNA replication in interphase. Similar findings were reported by Arshadullah et al. [84] and Hussain et al. [85].

Clearly, salinity reduced grain weight/plant for M-28 and LINE-6 genotypes from (13.29 and 6.26) at $60 \mathrm{mM} \mathrm{NaCl}$ to $(7.30 \mathrm{~g}$ and $2.63 \mathrm{~g})$ at $160 \mathrm{mM} \mathrm{NaCl}$, respectively. These results agreed, too, with those of Hussain et al. [85]. In the same context, the obtained results clarified that the lowest values of grain yield, 1000-grain weight, and harvest index were recorded for $160 \mathrm{mM} \mathrm{NaCl}$, while the highest values were recorded for the $60 \mathrm{mM}$ $\mathrm{NaCl}$ treatment. These results were in agreement with Miranda et al. [86], Hirich et al. [87], and Algosaibi et al. [88]. Also, the decrease in the number and size of the panicles/plant has been related to lower seed yield [87]. This phenomenon was also observed in our study. Koyro and Eisa [89] demonstrated that plant fresh weights were all significantly reduced in the presence of salinity.

On the other hand, the highest recorded means for $\mathrm{K}^{+}$contents and $\mathrm{Na}^{+}$were achieved by the M-28 genotype, while the lowest recorded means were obtained for the LINE- 6 genotype. Similarly, Orsini et al. [90] reported that $\mathrm{Na}^{+}$was induced by $150-750 \mathrm{mM}$ $\mathrm{NaCl}$ in Chilean cv. BO78. Because quinoa plants collect $\mathrm{Na}^{+}$, which is readily available for cytosolic osmotic adjustment and maintaining turgor pressure, the increased $\mathrm{Na}^{+}$ absorption should be followed by accelerated $\mathrm{K}^{+}$transport from root to shoot to maintain an appropriate $\mathrm{K}^{+}: \mathrm{Na}^{+}$ratio in leaves [91]. Our data demonstrated that $\mathrm{Na}^{+}$increased dramatically with increasing salinity in the leaves of the $\mathrm{M}-28$ genotype, with a rapid spike in $\mathrm{Na}^{+}$concentration occurring only at $160 \mathrm{mM}$, and a similar trend was seen in genotype LINE-6 genotype. In genotype $\mathrm{M}-28$, the $\mathrm{K}^{+}$concentration in leaves dropped with rising salinity levels at $160 \mathrm{mM}$, whereas it increased significantly in genotype M-28. Additionally, 
genotype M-28 was shown to be superior to genotype LINE-6 in terms of producing greater dry weight at the maximum salinity level, which was associated with greater leaf $\mathrm{K}^{+}$ accumulation than in genotype LINE-6. This result is in line with Saleem et al. [78]. The enhanced absorption of $\mathrm{K}^{+}$by the roots at increasing $\mathrm{Na}^{+}$levels may explain the M-28 genotype's resilience to salt stress. One of the most essential physiological indications for salt tolerance is proline accumulation [92]. A significant increase in proline content was detected under $160 \mathrm{mM}$ in leaves of the M-28 genotype. This result was in line with the findings of other researchers, including Prado et al. [93] and Derbali et al. [94].

Overall, all tested genotypes could survive under the highest salinity stress $(160 \mathrm{mM}$ $\mathrm{NaCl}$ ). Additionally, genotype M-28 was tolerant and the least affected, while genotype LINE-6 was sensitive and, following salinity treatment, its agro-physiological characteristics were drastically affected.

Plants undergo a variety of changes in response to abiotic stress, ranging from physiological adaptation to gene expression. Several species' pivotal genes associated with $\mathrm{Na}^{+}$transport have been cloned, and their role in salt tolerance has been examined [95]. In this study, both studied genotypes (tolerant and sensitive) exhibited a lower transcript abundance of CqSOS1 under $160 \mathrm{mM} \mathrm{NaCl}$, which disagrees with the acclimation role of the trait encoded by this gene. Our results agree with the finding of Maughan et al. [45], which states that saline treatment caused no significant expression of CqSOS1A and Cq$S O S 1 B$ genes in roots. This observation would suggest that this treatment did not induce $\mathrm{Na}^{+}$exclusion at the root level. On the contrary, in the absence of salinity, CqSOS1A and CqSOS1B were expressed more strongly in roots than in leaves; however, saline treatment produced an upregulation of both genes in leaves, indicating that cytoplasmic $\mathrm{Na}^{+}$was migrating out of the roots [45].

Under salt or osmotic stress, NHX proteins may provide protection by compartmentalizing $\mathrm{K}$ and $\mathrm{Na}$ in the vacuole, thereby preventing toxic $\mathrm{Na} / \mathrm{K}$ ratios in the cytosol. Overexpression of the NHX family of $\mathrm{Na}^{+} / \mathrm{H}^{+}$antiporters in diverse plant species has resulted in enhanced salt tolerance in many instances [96,97]. In this regard, the obtained results of $\mathrm{CqNHX1}$ expression were consistent with those of Ruiz et al. [75], who found that $300 \mathrm{mM} \mathrm{NaCl}$ increased CqNHX1 expression in the tolerant cultivar but not in the salt-sensitive cultivar, implying that compartmentation in the vacuole was not used in the latter. These results confirm our hypothesis regarding tolerance mechanisms in the studied genotypes. Moreover, detected differences in expression levels may indicate a preventative response rather than initiating expression upon stress. These results agreed with Ruiz et al. [75], who conducted a comparative analysis of three genes (CqNHX1, CqSOS1A, and $C q S O S 1 B)$ and found that saline conditions produced greater increments in $C q N H X 1$ than in $C q S O S 1 B$, with even less in CqSOS1A.

The combined morpho-physiological and molecular analysis is a target for breeding programs to enhance crop yield under drought stress [98] and salinity stress [64]. Salt stress led to morphological, physiological, biochemical, and molecular changes that adversely affected the studied genotype's growth and productivity. To completely comprehend the negative effects of high salinity in plants, several combined evaluations are required [99]. Significant interactions among genotype and irrigation conditions for several agronomical variables indicate the genotypic flexibility available to the species and the need to evaluate genotypic performance under each growing condition [100]. It is worth mentioning that the morpho-physiological and biochemical results proved that the M28 genotype is more tolerant than the LINE-6 genotype. This fact is linked to the higher level of CqNHX1 gene expression in the M28 genotype than in the LINE-6 genotype. In addition, the highest and lowest means of $\mathrm{K}^{+}$and $\mathrm{Na}^{+}$contents were recorded for the M28 genotype and LINE-6 genotype, respectively, indicating that vacuolar $\mathrm{Na}^{+}$or $\mathrm{K}^{+}$compartmentation is an important tolerance mechanism in the tolerant genotype and compartmentation in the vacuole was less active in the sensitive genotype. In the same way, these genotypes exhibited a wide range of genetic variability, with LINE-6 genotype generating more unique positive and negative bands ( 50 bands) than M28 genotype (42 bands) using ISSR and 
SCoT markers. These markers could have further potential in genotyping and revealing polymorphisms directly related to gene function.

\section{Conclusions}

The present study reinforces the utility of morpho-physiological, biochemical, and molecular analysis to select quinoa genotypes with variable performance under different salinity conditions. There was an association based on morpho-physiological and molecular data, which indicates that both types of characterization (phenotype and genotype) are essential for understanding the differentiation between quinoa genotypes. Moreover, the high genetic diversity found by SCoT, ISSR, and protein analysis could be exploited in breeding programs to obtain new cultivars and provide relevant information for diversity conservation. Moreover, there was a wide range of variability in all morpho-physiological and biochemical traits. There was upregulation of CqNHX1 and downregulation of CqSOS1 genes in leaf or root tissues of the studied genotypes. Our results revealed M-28 (tolerant) and Line-6 (sensitive) genotypes.

Supplementary Materials: The following are available online at https:/ /www.mdpi.com/article/ 10.3390/plants10122802/s1, Figure S1. Amplification products generated from ten ISSR primers. Figure S2. Amplification products generated from ten SCoT primers. Figure S3. Cluster Dendrogram of the studied quinoa genotypes based on UPGMA analysis using the similarity matrix generated by ISSR and SCoT markers. Figure S4. Cluster Dendrogram of the studied quinoa genotypes based on UPGMA analysis using the similarity matrix generated from morpho-physiological traits and molecular attributes (ISSR \&SCoT). Table S1. Sequences of ISSR and SCoT primers used in studying genetic diversity of quinoa. Table S2. Primer information used for gene expression analysis in Chenopodium quinoa. Table S3. Similarity correlation among selected genotypes of quinoa.

Author Contributions: Conceptualization, D.A.E.-M., E.I.S.E., A.M.E.-A. and A.A.I.; methodology, A.M.E.-A., D.A.E.-M. and A.A.I.; software, A.A.I. and D.A.E.-M.; validation, D.A.E.-M., E.I.S.E., A.M.E.-A. and A.A.I.; formal analysis, D.A.E.-M. and A.A.I.; investigation, D.A.E.-M., E.I.S.E., A.M.E.-A. and A.A.I.; D.A.E.-M., E.I.S.E., A.M.E.-A. and A.A.I.,.; data curation, A.A.I. and D.A.E.-M.; writing-original draft preparation, A.A.I. and D.A.E.-M.; writing-review and editing, All authors; visualization, S.A., S.M.A., F.A.A.S., D.A.E.-M., E.I.S.E., A.M.E.-A. and A.A.I. All authors have read and agreed to the published version of the manuscript.

Funding: This research received no external funding.

Institutional Review Board Statement: Not applicable.

Informed Consent Statement: Not applicable.

Data Availability Statement: Relevant data applicable to this research are within the paper.

Acknowledgments: This work is a special thanks to the soul of Diaa's father, who brought the motivation for his scientific career. A great acknowledgment to Nabil Saied Awad (Associate Professor of Genetics, Faculty of Agriculture and Natural resources, Aswan University) for his assistance in gene expression experiments.

Conflicts of Interest: The authors declare no conflict of interest.

\section{References}

1. González, J.A.; Hinojosa, L.; Mercado, M.I.; Fernández-Turiel, J.-L.; Bazile, D.; Ponessa, G.I.; Eisa, S.; González, D.A.; Rejas, M.; Hussin, S.; et al. A Long Journey of CICA-17 Quinoa Variety to Salinity Conditions in Egypt: Mineral Concentration in the Seeds. Plants 2021, 10, 407. [CrossRef] [PubMed]

2. Bazile, D.; Jacobsen, S.E.; Verniau, A. The global expansion of quinoa: Trends and limits. Front. Plant Sci. 2016, 7, 622-629. [CrossRef] [PubMed]

3. Gomez-Pando, L.R.; Aguilar-Castellanos, E.; Ibañez-Tremolada, M. Quinoa (Chenopodium quinoa Willd.) breeding. In Advances in Plant Breeding Strategies: Cereals; Al-Khayri, J., Jain, S., Johnson, D., Eds.; Springer: Cham, Switzerland, 2019 ; pp. $259-316$.

4. Adolf, V.I.; Shabala, S.; Andersen, M.N.; Razzaghi, F.; Jacobsen, S.E. Varietal differences of quinoa's tolerance to saline conditions. Plant Soil 2012, 357, 117-129. [CrossRef] 
5. Fuentes, F.; Bhargava, A. Morphological analysis of quinoa germplasm grown under lowland desert conditions. J. Agron. Crop Sci. 2011, 197, 124-134. [CrossRef]

6. González, J.A.; Eisa, S.S.S.; Hussin, S.A.E.S.; Prado, F.E. Quinoa: An incan crop to face global changes in agriculture. In Quinoa: Improvement and Sustainable Production; Murphy, K., Matanguihan, J., Eds.; John Wiley \& Sons, Inc.: Hoboken, NJ, USA, 2015; pp. 1-18, ISBN 978-1-118-62804-1.

7. Vilcacundo, R.; Hernández-Ledesma, B. Nutritional and biological value of quinoa (Chenopodium quinoa Willd.). Curr. Opin. Food Sci. 2017, 14, 1-6. [CrossRef]

8. Gordillo-Bastidas, E.; Díaz-Rizzolo, D.A.; Roura, E.; Massanés, T.; Gomis, R. Quinoa (Chenopodium quinoa Willd), from Nutritional Value to Potential Health Benefits: An Integrative Review. J. Nutr. Food Sci. 2016, 6, 497. [CrossRef]

9. Angeli, V.; Miguel Silva, P.; Crispim Massuela, D.; Khan, M.W.; Hamar, A.; Khajehei, F.; Graeff-Hönninger, S.; Piatti, C. Quinoa (Chenopodium quinoa Willd.): An Overview of the Potentials of the "Golden Grain" and Socio-Economic and Environmental Aspects of Its Cultivation and Marketization. Foods 2020, 9, 216. [CrossRef] [PubMed]

10. Bazile, D.; Fuentes, F.; Mujica, A. Historical perspectives and domestication. In Quinoa: Botany, Production and Uses; Bhargava, A., Srivastava, S., Eds.; CABI: Wallingford, UK, 2013; pp. 16-35.

11. Christensen, S.; Pratt, D.B.; Pratt, C.; Nelson, P.T.; Stevens, M.R.; Jellen, E.N.; Coleman, C.E.; Fairbanks, D.J.; Bonifacio, A.; Maughan, P.J. Assessment of genetic diversity in The USDA and CIP-FAO international nursery collections of quinoa (Chenopodium quinoa Willd.) using microsatellite markers. Plant Genet. Resour. 2007, 5, 82-95. [CrossRef]

12. Li, G.; Quiros, C.F. Sequence-Related amplified polymorphism (SRAP), a new marker system based on a simple PCR reaction: Its application to mapping and gene tagging in Brassica. Theor. Appl. Genet. 2001, 103, 455-461. [CrossRef]

13. Salazar, J.; Torres, M.D.L.; Gutierrez, B.; Torres, A.F. Molecular characterization of Ecuadorian quinoa (Chenopodium quinoa Willd.) diversity: Implications for conservation and breeding. Euphytica 2019, 215, 60. [CrossRef]

14. Zhang, T.; Gu, M.; Liu, Y.; Lv, Y.; Zhou, L.; Lu, H.; Liang, S.; Bao, H.; Zhao, H. Development of novel InDel markers and genetic diversity in Chenopodium quinoa through whole-genome re-sequencing. BMC Genom. 2017, 18, 685. [CrossRef] [PubMed]

15. Mason, S.; Stevens, M.R.; Jellen, E.N.; Bonifacio, A.; Fairbanks, D.J.; Coleman, C.E.; McCarty, R.R.; Rasmussen, A.G.; Maughan, P.J. Development and use of microsatellite markers for germplasm characterization in quinoa (Chenopodium quinoa Willd.). Crop Sci. 2005, 45, 1618-1630. [CrossRef]

16. Konishi, Y.; Hirano, S.; Tsuboi, H.; Wada, M. Distribution of minerals in quinoa (Chenopodium quinoa Willd) seeds. Biosci. Biotechnol. Biochem. 2004, 68, 231-234. [CrossRef] [PubMed]

17. Prado, F.E.; Fernández-Turiel, J.L.; Tsarouchi, M.; Psaras, G.K.; González, J.A. Variation of seed mineral concentrations in seven quinoa cultivars grown in two agroecological sites. Cereal Chem. J. 2014, 91, 453-459. [CrossRef]

18. Jaime-Pérez, N.; Pineda, B.; García-Sogo, B.; Atares, A.; Athman, A.; Byrt, C.S.; Olías, R.; Asins, M.J.; Gilliham, M.; Moreno, V.; et al. The sodium transporter encoded by the HKT1;2 gene modulates sodium/potassium homeostasis in tomato shoots under salinity. Plant Cell Environ. 2017, 40, 658-671. [CrossRef] [PubMed]

19. Cai, Z.Q.; Gao, Q. Comparative physiological and biochemical mechanisms of salt tolerance in five contrasting highland quinoa cultivars. BMC Plant Biol. 2020, 20, 70. [CrossRef] [PubMed]

20. Kiani-Pouya, A.; Rasouli, F.; Shabala, L.; Tahir, A.T.; Zhou, M.; Shabala, S. Understanding the role of root-related traits in salinity tolerance of quinoa accessions with contrasting epidermal bladder cell patterning. Planta 2020, 251, 103. [CrossRef]

21. Caperta, A.D.; Róis, A.S.; Teixeira, G.; Garcia-Caparros, P.; Flowers, T.J. Secretory structures in plants: Lessons from the Plumbaginaceae on their origin, evolution and roles in stress tolerance. Plant Cell Environ. 2020, 43, 2912-2931. [CrossRef]

22. Kotula, L.; Garcia Caparros, P.; Zörb, C.; Colmer, T.D.; Flowers, T.J. Improving crop salt tolerance using transgenic approaches: An update and physiological analysis. Plant Cell Environ. 2020, 4, 2932-2956. [CrossRef] [PubMed]

23. Shabala, S.; Chen, G.; Chen, Z.H.; Pottosin, I. The energy cost of the tonoplast futile sodium leak. New Phytol. 2020, 225, 1105-1110. [CrossRef] [PubMed]

24. Buhulikar, R.A.; Stanculescu, D.; Preston, C.A.; Baldwin, I.T. ISSR and AFLP analyses of the temporal and spatial population structure of the post-fire annual Nicotiana attenuate in SW, Utah. BMC Ecol. 2004, 4, 12.

25. Collard, B.C.Y.; Mackill, D.J. Start Codon Targeted (SCoT) Polymorphism: A Simple, Novel DNA Marker Technique for Generating Gene-Targeted Markers in Plants. Plant Mol. Biol. Rep. 2009, 27, 86-93. [CrossRef]

26. Xiong, F.Q.; Tang, R.H.; Chen, Z.L.; Pan, L.H.; Zhuang, W.J. SCoT: A novel gene targeted marker technique based on the translation start codon. Mol. Plant Breed. 2009, 7, 635-638.

27. Romero, G.; Adeva, C.; Battad, Z. Genetic fingerprinting: Advancing the frontiers of crop biologyresearch. Philipp. Sci. Lett. 2009, 2, 8-13.

28. Bafeel, S.O.; Ibrahim, A.A.; Ali, A.A.; Haseeb, A.K.; Anis, A.; Mohammad, A.B. Assessment of DNA barcoding for the identification of Chenopodium murale L. (Chenopodiaceae). Int. J. Biol. Citeseer 2012, 4, 66. [CrossRef]

29. Ibrahim, S.D.; Abd El-Hakim, A.F.; Ali, H.E.; Abd El-Maksoud, R.M. Genetic differentiation using ISSR, SCoT and DNA Barcoding for Quinoa genotypes. Arab. J. Biotech. 2019, 22, 103-118.

30. Lema-Rumińska, J.; Miler, N.; Gęsiński, K. Identification of new polish lines of Chenopodium quinoa (Willd.) by spectral analysis of pigments and a confirmation of genetic stability with SCoT and RAPD markers. Acta Sci. Pol. Hortorum Cultus 2018, 17, 75-86. [CrossRef] 
31. Omar, S.A.; Masoud, I.M.; Khalil, R.M.A. Genetic evaluation of some quinoa genotypes under ras suder conditions. J. Plant Prod. Mansoura Univ. 2014, 5, 1915-1930.

32. Devi, R.J.; Chrungoo, N.K. Species relationships in Chenopodium quinoa and Chenopodium album on the basis of morphology and SDS-PAGE profiles of soluble seed proteins. J. App. Biol. Biotech. 2015, 3, 29-33. [CrossRef]

33. Ruiz, K.B.; Aloisi, I.; Del Duca, S.; Canelo, V.; Torrigiani, P.; Silva, H.; Biondi, S. Salares versus coastal ecotypes of quinoa: Salinity responses in Chilean landraces from contrasting habitats. Plant Physiol. Biochem. 2016, 101, 1-13. [CrossRef] [PubMed]

34. Barlett, M.S. Some samples of statistical method of research in agriculture and applied biology. J. R. Stat. Soc. 1973, 4, 137-183.

35. Radford, P.J. Growth analysis formulae, their use and abuse. Crop Sci. 1967, 7, 171-175. [CrossRef]

36. Beadle, C.L. Growth analysis. In Photosynthesis and Production in a Changing Environment: A Field and Laboratory Manual; Hall, D.O., Scurlock, J.M.O., Bolhàr-Nordenkampf, H.R., Leegood, R.C., Long, S.P., Eds.; Chapman and Hall: London, UK, 1993 ; pp. 36-46.

37. Association of Official Analytical Chemists (AOAC). Official Methods of Analysis of the Association of Official Analytical Chemists, 17th ed.; Association of Official Analytical Chemists: Washington, DC, USA, 2000.

38. Bates, L.S.; Waldren, R.P.; Teare, I.D. Rapid determination of free proline for water-stress studies. Plant Soil 1973, $39,205-207$. [CrossRef]

39. Jackson, M.L. Soil Chemical Analysis, 1st ed.; Prentice Hall of India Private Limited: New Delhi, India, 1973.

40. Cota-Sanchez, H.; Remarchuk, K.; Ubayasenaj, K. Ready-to-use DNA extracted with a CTAB method adapted for herbarium specimens and mucilaginous plant tissue. Plant Mol. Biol. Rep. 2006, 24, 161-167. [CrossRef]

41. Zietkiewicz, E.; Rafalski, A.; Labuda, D. Genome fingerprinting by simple sequence repeat (SSR)-anchored polymerase chain reaction amplification. Genomics 1994, 20, 176-183. [CrossRef] [PubMed]

42. Anderson, J.A.; Churchill, G.A.; Autrique, J.E. Optimizing pa-rental selection for genetic linkage maps. Genome 1993, 36, 181-186. [CrossRef] [PubMed]

43. Bradford, M.M. A rapid and sensitive m method for the quantification of micrograms of protein utilizing the principal dye binding. Anal. Biochem. 1976, 72, 248-254. [CrossRef]

44. Laemmli, U.K. Cleavage of structural proteins during the assembly of the head of bacteriophage T4. Nature 1970, 227, 680-685. [CrossRef] [PubMed]

45. Maughan, P.J.; Turner, T.B.; Coleman, C.E.; Elzinga, D.B.; Jellen, E.N.; Morales, J.A.; Udall, J.A.; Fairbanks, D.J.; Bonifacio, A. Characterization of salt overly sensitive 1 (SOS1) gene homoeologs in quinoa (Chenopodium quinoa Willd.). Genome 2009, 52, 647-657. [CrossRef] [PubMed]

46. Morales, A.J.; Bajgain, P.; Garver, Z.; Maughan, P.J.; Udall, J.A. Physiological responses of Chenopodium quinoa to salt stress. Int. J. Plant. Physiol. Biochem. 2011, 3, 219-232.

47. Balzotti, M.R.B.; Jellen, E.N.; Fairbanks, D.J.; Coleman, C.E.; Stevens, M.R.; Thornton, J.N.; Maughan, P.J.; Mcclellan, D.A. Expression and evolutionary relationships of the Chenopodium quinoa 11S seed storage protein gene. Int. J. Plant Sci. 2008, 169, 281-291. [CrossRef]

48. Duncan, D.B. Multiple range and multiple F tests. Biometrics 1955, 11, 1-41. [CrossRef]

49. Hammer, D.A.T.; Ryan, P.D.; Hammer, Ø.; Harper, D.A.T. Past: Paleontological Statistics Software Package for Education and Data Analysis. Palaeontol. Electron. 2001, 4, 1-9.

50. Chen, C.; Chen, H.; Zhang, Y.; Thomas, H.R.; Frank, M.H.; He, Y.; Xia, R. TBtools: An Integrative Toolkit Developed for Interactive Analyses of Big Biological Data. Mol. Plant 2020, 13, 1194-1202. [CrossRef] [PubMed]

51. Sokal, R.R.; Michener, C.D. A statistical method for evaluating systematic relationships. Univ. Kans. Sci. Bull. 1958, 38, 1409-1438.

52. Fuentes, F.F.; Martinez, E.A.; Hinrichsen, P.V.; Jellen, E.N.; Maughan, P.J. Assessment of genetic diversity patterns in Chilean quinoa (Chenopodium quinoa Willd.) germplasm using multiplex fluorescent microsatellite markers. Conserv. Genet. 2009, 10, 369-377. [CrossRef]

53. Lu, M.; Mo, X.; Wang, Q.; Lu, G.; Jiang, Y. Comparison of Genomic DNA Extraction Methods for Chenopodium quinoa Willd. Agric. Sci. Technol. 2015, 6, 1343.

54. Rodríguez, A.L.; Isla, M. Comparative analysis of genetic and morphologic diversity among quinoa accessions (Chenopodium quinoa Willd.) of the South of Chile and highland accessions. J. Plant Breed. Crop Sci. 2009, 1, 210-216.

55. Al-Naggar, A.M.M.; Sobieh, S.E.S.; Atta, M.M.M.; Al-Azab, K.F. Unique SSR markers for drought tolerance in bread wheat mutants derived via exposure to gamma rays. World Res. J. Agron. 2013, 2, 15-25.

56. Al-Naggar, A.M.M.; Al-Azab, K.F.; Sobieh, S.E.S.; Atta, M.M.M. Molecular analysis of new drought tolerant segregants selected from F2 populations of bread wheat crosses. World Res. J. Agron. 2013, 3, 58-69.

57. Ana-Cruz, M.C.; Helena, M.E.; Yacenia, M.C. Molecular characterization of Chenopodium quinoa Willd. using inter-simple sequence repeat (ISSR) markers. Afr. J. Biotechnol. 2017, 16, 483-489.

58. Al-Naggar, M.M.; Abd El-Salam, R.M.; Badran, A.E.E.; Mai El-Moghazi, M.M.A. Molecular Differentiation of Five Quinoa (Chenopodium quinoa Willd.) Genotypes Using Inter-simple Sequence Repeat (ISSR) Markers. Biotechnol. J. Int. 2017, 20, 1-12. [CrossRef]

59. Saad-Allah, K.M.; Youssef, M.S. Phytochemical and genetic characterization of five quinoa (Chenopodium quinoa Willd.) genotypes introduced to Egypt. Physiol. Mol. Biol. Plants 2018, 24, 617-629. [CrossRef] [PubMed]

60. Botstein, D.; White, R.L.; Skolnick, M.; Davis, R.W. Construction of a genetic linkage map in man using restriction fragment length polymorphisms. Am. J. Hum. Genet. 1980, 32, 314-331. [PubMed] 
61. Laosatit, K.; Taytragool, S.; Pimsaythong, K.; Somta, P.; Tanadul, O. Genetic diversity of Quinoa (Chenopodium quinoa Willd.) germplasm as revealed by sequence-related amplified polymorphism markers. Agr. Nat. Resour. 2021, 55, 341-348.

62. EL-Harty, E.H.; Ghazy, A.; Alateeq, T.K.; Al-Faifi, S.A.; Khan, M.A.; Afzal, M.; Alghamdi, S.S.; Migdadi, H.M. Morphological and Molecular Characterization of Quinoa Genotypes. Agriculture 2021, 11, 286. [CrossRef]

63. Abd El-Moneim, D. Characterization of ISSR and SCoT Markers and TaWRKY Gene Expression in some Egyptian Wheat Genotypes under Drought Stress. J. Plant Prod. Sci. 2019, 8, 31-46.

64. Gowayed, S.M.H.; Abd El-Moneim, D. Detection of genetic divergence among some wheat (Triticum aestivum L.) genotypes using molecular and biochemical indicators under salinity stress. PLoS ONE 2021, 16, e0248890. [CrossRef] [PubMed]

65. EL-Mansy, A.B.; Abd El-Moneim, D.; ALshamrani, S.M.; Alsafhi, F.A.; Abdein, M.A.; Ibrahim, A.A. Genetic Diversity Analysis of Tomato (Solanum lycopersicum L.) with Morphological, Cytological, and Molecular Markers under Heat Stress. Horticulturae 2021, 7, 65. [CrossRef]

66. Abdein, M.A.; Abd El-Moneim, D.; Taha, S.S.; Al-Juhani, W.S.M.; Mohamed, S.E. Molecular characterization and genetic relationships among some tomato genotypes as revealed by ISSR and SCoT markers. Egypt. J. Genet. Cytol. $2018,47,139-159$.

67. Abdein, M.A.; El-Mansy, A.B.; Awad, N.S.; Abd El-Moneim, D. Assessment of Genetic Diversity in Summer Squash Genotypes Using Fruit Morphological, Yield Traits and DNA Markers Analysis under Sinai Conditions. J. Plant Prod. Sci. 2021, $10,13-29$.

68. Stuardo, M.; Martín, R.S. Antifungal properties of quinoa (Chenopodium quinoa Willd.) alkali treated saponins against botrytis cinerea. Ind. Crop. Prod. 2008, 27, 296-302. [CrossRef]

69. Sadia, M.; Malik, S.A.; Rabbani, M.A.; Pearce, S.R. Electrophoretic characterization and the relationship between some Brassica species. Electr. J. Biol. 2009, 5, 1-4.

70. Soliman, M.I.; Ibrahim, A.A.; Rizk, R.M.; Naser, N.S. Phytoremediation, Biochemical and Molecular Studies of Some Selected Hydrophytes in Egypt. J. Appl. Sci. 2019, 19, 708-717. [CrossRef]

71. Soliman, M.I.; Ibrahim, A.A.; Samaan, L.Z.; Sedky, E. Comparative Studies Between Annual and Perennial Sesbania Using Karyological, Biochemical and Molecular Studies. J. Appl. Sci. 2019, 19, 593-604. [CrossRef]

72. Aloisi, I.; Parrotta, L.; Ruiz, K.B.; Landi, C.; Bini, L.; Cai, G.; Biondi, S.; Del Duca, S. New insight into quinoa seed quality under salinity: Changes in proteomic and amino acid profiles, phenolic content, and antioxidant activity of protein extracts. Front. Plant Sci. 2016, 7, 656. [CrossRef]

73. Schmöckel, S.M.; Lightfoot, D.J.; Razali, R.; Tester, M.; Jarvis, D.E. Identification of putative transmembrane proteins involved in salinity tolerance in Chenopodium quinoa by integrating physiological data, RNAseq, and SNP analyses. Front. Plant Sci. 2017, 8 , 1023. [CrossRef]

74. Debez, A.; Hamed, K.B.; Grignon, C.; Abdelly, C. Salinity effects on germination, growth, and seed production of the halophyte Cakile maritima. Plant Soil 2004, 262, 179-189. [CrossRef]

75. Ruiz-Carrasco, K.; Antognoni, F.; Coulibaly, A.K.; Lizardi, S.; Covarrubias, A.; Martínez, E.A.; Molina-Montenegro, M.A.; Biondi, S.; Zurita-Silva, A. Variation in salinity tolerance of four lowland genotypes of quinoa (Chenopodium quinoa Willd.) as assessed by growth, physiological traits, and sodium transporter gene expression. Plant Physiol. Biochem. 2011, 49, 1333-1341. [CrossRef] [PubMed]

76. Razzaghi, F.; Jacobsen, S.E.; Jensen, C.R.; Andersen, M.N. Ionic and photosynthetic homeostasis in quinoa challenged by salinity and drought-Mechanisms of tolerance. Func. Plant Biol. 2015, 42, 136-148. [CrossRef] [PubMed]

77. Tan, M.; Akçay, E. Temperature and salinity effects on germination of some quinoa (Chenopodium quinoa Willd) cultivars. In Proceedings of the 89th IRES International Conference, Helsinki, Finland, 17-18 November 2017; pp. 3-5.

78. Saleem, M.A.; Basra, S.M.A.; Afzal, I.; Rehman, H.U.; Iqbal, S.; Saddiq, M.S.; Naz, S. Exploring the potential of quinoa accessions for salt tolerance in soilless culture. Int. J. Agric. Biol. 2017, 19, 233-240. [CrossRef]

79. Long, N. Genetic Variation in Response to Salt Stress of Quinoa Grown under Controlled and Field Conditions. Int. J. Adv. Sci. Eng. Inf. Technol. 2016, 6, 233. [CrossRef]

80. Talebnejad, R.; Sepaskhah, A.R. Physiological characteristics, gas exchange, and plant ion relations of Quinoa to different saline groundwater depths and water salinity. Arch. Agron. Soil Sci. 2016, 62, 1347-1367. [CrossRef]

81. Islam, M.T.; Saiful Islam, A.F.M.; Sharaf Uddin, M. Physiological Growth Indices of Maize (Zea mays L.) Genotypes in Sylhet. bioRxiv 2019. [CrossRef]

82. Riccardi, M.; Pulvento, C.; Lavini, A.; D’Andria, R.; Jacobsen, S.-E. Growth and Ionic Content of Quinoa Under Saline Irrigation. J. Agron. Crop. Sci. 2014, 200, 246-260. [CrossRef]

83. Jacobsen, S.E.; Quispe, H.; Mujica, A. Quinoa: An alternative crop for saline soils in the Andes. In Scientists and Farmer-Partners in Research for the 21st Century, 2001 CIP Program Report 1999-2000; International Potato Center (Centro Internacional de la Papa) (CIP): Lima, Peru, 2001; pp. 403-408.

84. Arshadullah, M.; Suhaib, M.; Usama, M.; uz-Zaman, B.; Mahmood, I.A.; Hyder, S.I. Effect of salinity on growth of Chenopodium quinoa Willd. Int. J. Res. Agric. For. 2016, 11, 21-24.

85. Hussain, M.I.; Muscolo, A.; Ahmed, M.; Asghar, M.A.; Al-Dakheel, A.J. Agro-Morphological, Yield and Quality Traits and Interrelationship with Yield Stability in Quinoa (Chenopodium quinoa Willd.) Genotypes under Saline Marginal Environment. Plants 2020, 9, 1763. [CrossRef] [PubMed] 
86. Miranda, M.; Vega-Gálvez, A.; Martínez, E.A.; López, J.; Marín, J.; Aranda, M.; Fuentes, F. Influence of contrasting environments on seed composition of two quinoa genotypes: Nutritional and functional properties. Chilean J. Agric. Res. 2013, 73, 108-116. [CrossRef]

87. Hirich, A.; Choukr-Allah, R.; Jacobsen, S.E. Deficit irrigation and organic compost improve growth and yield of Quinoa and pea. J. Agron. Crop. Sci. 2014, 200, 390-398. [CrossRef]

88. Algosaibi, A.M.; El-Garawany, M.M.; Badran, A.E.; Almadini, A.M. Effect of irrigation water salinity on the growth of quinoa plant. J Agric. Sci. 2015, 7, 205. [CrossRef]

89. Koyro, H.W.; Eisa, S.S. Effect of salinity on composition, viability, and germination of seeds of Chenopodium quinoa Willd. Plant Soil 2008, 302, 79-90. [CrossRef]

90. Orsini, F.; Accorsi, M.; Gianquinto, G.; Dinelli, G.; Antognoni, F.; Carrasco, K.B.R.; Martinez, E.A.; Alnayef, M.; Marotti, I.; Bosi, S.; et al. Beyond the ionic and osmotic response to salinity in Chenopodium quinoa: Functional elements of successful halophytism. Funct. Plant Biol. 2011, 38, 818-831. [CrossRef] [PubMed]

91. Cuin, T.A.; Tian, Y.; Betts, S.A.; Chalmandrier, R.; Shabala, S. Ionic relations and osmotic adjustment in durum and bread wheat under saline conditions. Funct. Plant Biol. 2009, 36, 1110-1119. [CrossRef] [PubMed]

92. Mansour, M.M.F.; Ali, E.F. Evaluation of proline functions in saline conditions. Phytochemistry 2017, 140, 52-68. [CrossRef] [PubMed]

93. Prado, F.; Hilal, M.B.; Albornoz, P.L.; Gallardo, M.G.; Ruiz, V.E. Anatomical and physiological responses of four quinoa cultivars to salinity at seedling stage. Indian J. Sci. Technol. 2017, 10, 1-12. [CrossRef]

94. Derbali, W.; Goussi, R.; Koyro, H.-W.; Abdelly, C.; Manaa, A. Physiological and biochemical markers for screening salt tolerant quinoa genotypes at early seedling stage. J. Plant Interact. 2020, 15, 27-38. [CrossRef]

95. Shi, H.; Quintero, F.J.; Pardo, J.M.; Zhu, J.-K. The Putative Plasma Membrane Na ${ }^{+} / \mathrm{H}^{+}$Antiporter SOS1 Controls Long-Distance $\mathrm{Na}^{+}$Transport in Plants. Plant Cell 2002, 14, 465-477. [CrossRef] [PubMed]

96. Xu, K.; Hong, P.; Luo, L.; Xia, T. Overexpression of AtNHX1, a vacuolar Na/H antiporter from Arabidopsis thaliana, in Petunia hybrida enhances salt and drought tolerance. J. Plant Biol. 2009, 52, 453-461. [CrossRef]

97. Rowley, E.R.; Mockler, T.C. Role of plant transcription factors in biotic stress tolerance. In Abiotic Stress Response in Plants Physiological, Biochemical and Genetic Perspectives; Shanker, A.K., Venkateswarlu, B., Eds.; InTech: Rijeka, Croatia, 2011; pp. 221-268.

98. Haddoudi, L.; Hdira, S.; Hanana, M.; Romero, I.; Haddoudi, I.; Mahjoub, A.; Ben Jouira, H.; Djébali, N.; Ludidi, N.; SanchezBallesta, M.T.; et al. Evaluation of the Morpho-Physiological, Biochemical and Molecular Responses of Contrasting Medicago truncatula Lines under Water Deficit Stress. Plants 2021, 10, 2114. [CrossRef]

99. Abd El-Moneim, D.; Alqahtani, M.M.; Abdein, M.A.; Germoush, M.O. Drought and salinity stress response in wheat: Physiological and TaNAC gene expression analysis in contrasting Egyptian wheat genotypes. J. Plant Biotechnol. 2020, 47, 1-14. [CrossRef]

100. Shabala, S.; Hariadi, Y.; Jacobsen, S.-E. Genotypic difference in salinity tolerance in quinoa is determined by differential control of xylem $\mathrm{Na}^{+}$loading and stomatal density. J. Plant Physiol. 2013, 170, 906-914. [CrossRef] [PubMed] 